\title{
Gene flow between diploid and tetraploid junipers - two contrasting evolutionary pathways in two Juniperus populations
}

\author{
Perla Farhat ${ }^{1,2^{*}}$ (D, Sonja Siljak-Yakovlev ${ }^{3}$, Nicolas Valentin ${ }^{4}$, Carlos Fabregat ${ }^{5}$, Silvia Lopez-Udias ${ }^{5}$,
} Carlos Salazar-Mendias ${ }^{6}$, Joaquín Altarejos ${ }^{7}$ and Robert P. Adams ${ }^{1}$

\begin{abstract}
Background: Gene flow and polyploidy have been found to be important in Juniperus evolution. However, little evidence has been published elucidating the association of both phenomena in juniper taxa in the wild. Two main areas were studied in Spain (Eastern Iberian Range and Sierra de Baza) with both diploid and tetraploid taxa present in sympatry. Gene flow and ploidy level were assessed for these taxa and the resulted offspring.

Results: Twenty-two allo-triploid hybrids between J. sabina var. sabina and J. thurifera were found in the Eastern Iberian Range population. However, in the Sierra de Baza population no triploids were found. Instead, 18 allotetraploid hybrids between two tetraploid taxa: J. sabina var. balkanensis and J. thurifera were discovered. High genetic diversity was exhibited among the tetraploid hybrids at Sierra de Baza, in contrast to the genetically identical triploid hybrids at the Eastern Iberian Range; this suggests meiotic difficulties within the triploid hybrids. In addition, unidirectional gene flow was observed in both studied areas.

Conclusion: Polyploidy and hybridization can be complementary partners in the evolution of Juniperus taxa in sympatric occurrences. Juniperus was shown to be an ideal coniferous model to study these two phenomena, independently or in concert.
\end{abstract}

Keywords: Juniperus, Gene flow, Polyploidy, Triploid bridge, Hybridization, Introgression, Spain, Conifer evolution

\section{Background}

Hybridization and polyploidy have been found to be widespread among plant groups, shaping their evolution and adaptation $[1,2]$. The conifers, however, seem to differ from angiosperms in that hybridization has been found to be more common than polyploidy, which has been estimated to be very rare at approximately $1.5 \%[3,4]$. Recently, the Juniperus L., a monophyletic Cupressaceae genus, $[5,6]$ was shown to have an exceptional high rate of polyploidy

\footnotetext{
* Correspondence: perla.farhat@net.usj.edu.lb

${ }^{1}$ Biology Department, Baylor University, Waco, TX 76798, USA

${ }^{2}$ Present address: Key Laboratory of Bio-resources and Eco-environment, College of Life Sciences, Sichuan University, Chengdu, Sichuan 610064, China Full list of author information is available at the end of the article
}

compared to all other conifers [7]. Juniperus is the most diverse genus within the Cupressaceae and the second within conifers. It contains 75 species and 40 varieties in 3 monophyletic sections Caryocedrus, Juniperus and Sabina [6]. A recent study of this genus discovered $15 \%$ of the taxa are tetraploid $(2 n=$ $4 x=44)$ and one taxon, Juniperus foetidissima Willd., is a hexaploid $(2 n=6 x=66)$ [7]. Thus, polyploidy has been shown to be highly implicated in Juniperus evolution. In addition, hybridization has been found to be an important phenomenon in Juniperus with many cases of hybridization reported including: J. arizonica (R. P. Adams) R. P. Adams x J. coahuilensis (Mart.) Gaussen ex R. P. Adams [8], J. maritima R. P. Adams

C C The Author(s). 2020 Open Access This article is licensed under a Creative Commons Attribution 4.0 International License, which permits use, sharing, adaptation, distribution and reproduction in any medium or format, as long as you give appropriate credit to the original author(s) and the source, provide a link to the Creative Commons licence, and indicate if changes were made. The images or other third party material in this article are included in the article's Creative Commons licence, unless indicated otherwise in a credit line to the material. If material is not included in the article's Creative Commons licence and your intended use is not permitted by statutory regulation or exceeds the permitted use, you will need to obtain permission directly from the copyright holder. To view a copy of this licence, visit http://creativecommons.org/licenses/by/4.0/ The Creative Commons Public Domain Dedication waiver (http://creativecommons.org/publicdomain/zero/1.0/) applies to the data made available in this article, unless otherwise stated in a credit line to the data. 
x J. scopulorum Sarg. [9, 10], J. virginiana var. silicicola (Small) E. Murray x J. bermudiana L. [11], J. virginiana L. $\mathrm{x} J$. horizontalis Moench [12] and J. osteosperma (Torr.) Little x J. occidentalis Hook. [13, 14]. The evolutionary impact of hybridization coupled with polyploidy through allopolyploidy has not been very well elaborated to date in Juniperus.

However, recently, a potential allo-tetraploid taxon, Juniperus sabina var. balkanensis R. P. Adams and A. N. Tashev has been discovered $[15,16]$. This variety was described principally based on the DNA sequence differences with only a few morphological differences with its sister variety, J. sabina var. sabina [15]. The newly described variety was shown to have participated in a chloroplast capture event from J. thurifera L., following an ancient hybridization between the tetraploid J. thurifera and the diploid J. sabina [15]. All populations of $J$. sabina var. balkanensis, analyzed at present, have been found to be tetraploid. In contrast, all samples of $J$. sabina var. sabina have been found to be diploid [16]. The current known geographical distribution does not overlap, even though the distribution of J. sabina var. sabina is widespread from Spain into China. Currently, J. sabina var. balkanensis has been confirmed by DNA analyses from Italy, the Balkans and the western part of Turkey [17]. Despite the difference in ploidy level between $J$. thurifera $(2 n=4 x)$ and J. sabina var. sabina $(2 n=2 x)$, first evidence of allo-triploid hybrids between those two taxa have been recently discovered in the French Alps, where the taxa occur in sympatry [18]. However, in Spain, J. sabina var. sabina and J. thurifera are occasionally sympatric and a putative hybrid has been described as Juniperus $x$ cerropastorensis J.M. Aparicio \& P.M. Uribe-Echebarria, based on their intermediate morphology [19].

The hybrid has an irregular, shrubby shape (Fig. 1), not erect as J. thurifera, nor as prostrate as J. sabina. Those potential hybrids differ by their shape and branches, female cone size, and the number of seeds per female cone. Juniperus $x$ cerropastorensis has been reported in a small area in Spain: in three counties; Castellón, Teruel and Valencia in the Eastern Iberian Range [19].

Because no molecular evidence has been reported on these putative hybrid plants, one objective of this study was to confirm the hybridization between J. sabina and J. thurifera based on nuclear and chloroplast markers in areas of geographical sympatry in Spain. Because the putative parents (J. sabina and $J$. thurifera) are respectively diploid and tetraploid, ploidy of the hybrid(s) is of considerable interest. Therefore, the ploidy levels of the samples were determined by flow cytometry. The extreme rarity of inter-ploidy interspecific hybridization in conifers in the wild makes studying these juniper

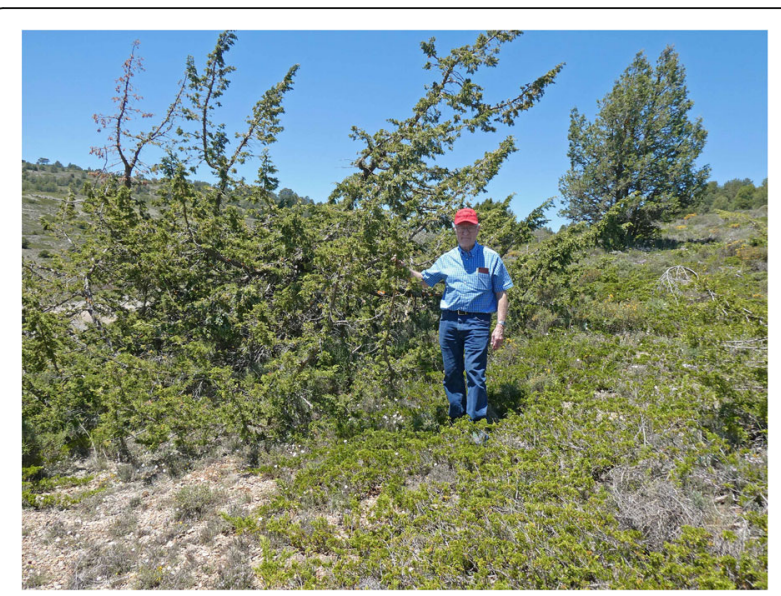

Fig. 1 Juniperus studied taxa from Eastern Iberian Range. Juniperus sabina (prostrate, lower right), J. thurifera (tree, upper right) and hybrid Adams 15655 (shrub, center-left) with RPA. Photo by CF.

putative hybrids of high importance especially for discovering potential pathways of evolution in this genus.

In addition, the only locality found to date, where the tetraploid J. sabina var. balkanensis and the diploid J. sabina var. sabina grow in sympatry is at Sierra de Baza, Granada province, Spain. Thus, our second aim was to study this unusual opportunity to find out if these two varieties interact together via gene flow and to measure the resulting ploidy level of hybrids (if any). This rare case of sympatry is a significant event that may give insight into the reproductive evolution of varieties (or taxa) with different ploidy levels within the same species of juniper.

\section{Results}

Genome size of parents and putative hybrids

Genome size (GS) was successfully assessed for all individuals sampled from the Eastern Iberian Range (hereafter referred to as E Iberian Range) and Sierra de Baza areas.

In the E Iberian Range, J. thurifera showed a genome size ranging from $41.79 \mathrm{pg}$ to $44.84 \mathrm{pg}$ with a mean of $42.55 \mathrm{pg}(\sigma=0.86 \mathrm{pg})$. Juniperus sabina sampled from this population hold a genome size of $20.79 \mathrm{pg}$ to 22.51 $\mathrm{pg}$ with a mean of $21.83 \mathrm{pg}(\sigma=0.41 \mathrm{pg})$.

The $22 \mathrm{~J} . x$ cerropastorensis samples (putative hybrids based on field observations) showed a genome size from $31.63 \mathrm{pg}$ to $35.22 \mathrm{pg}$ with a mean GS of $33.24 \mathrm{pg}(\sigma=0.83 \mathrm{pg})$.

In the Sierra de Baza, thirty samples of J. sabina ( $J$. sabina var. sabina and J. sabina var. balkanensis) were studied where two groups of GS were found. The first group containing 21 individuals varied in GS from $41 \mathrm{pg}$ to $46.05 \mathrm{pg}$, with a mean of $43.14 \mathrm{pg}(\sigma=1.33 \mathrm{pg})$. The second group consists of 9 shrubs with a measured GS 
from $21.39 \mathrm{pg}$ to $22.48 \mathrm{pg}$ and a mean of $22.09 \mathrm{pg}(\sigma=$ $0.35 \mathrm{pg}$ ).

Detailed values for each sample, indicating also the quality of the measurement by the coefficient of variation $(\mathrm{CV} \%)$, are represented in the additional file 1.

\section{Hybridization between J. sabina and J. thurifera in sympatry}

The chloroplast (cp) region trnS-trnG, amplified for all samples, generated sequences with $835 \mathrm{bp}$. We found 6 fixed single nucleotide polymorphisms (SNPs) and 2 indels between the cp sequences of J. thurifera (referred to thu cp Type) and J. sabina var. sabina (referred to sab cp Type) (Table 1). Surprisingly, all the putative hybrids (J. $x$ cerropastorensis) found in the E Iberian Range populations had the same cp sequence as J. thurifera (thu cp Type).

Sequencing the nuclear DNA (nrDNA) region, Internal Transcribed Spacer (ITS) generated 1270-1273 bp and revealed 23 informative SNPs and one indel at site 801(deletion in J. sabina var. sabina or an addition in $J$. thurifera). It is interesting that the same deletion at 801 occurs in the nrDNA of J. sabina var. balkanensis. Two of the SNPs were very near site 801 and could not be consistently scored, and were not utilized, resulting in 21 informative SNPs (Table 1). ITS data resolved the samples from E Iberian Range populations into five groups (Table 1): 1 . Ten individuals of $J$. thurifera (thu) (red, Table 1); 2. Eleven J. sabina var. sabina, Type1 haplotype (sabT1), which are very uniform (green, Table 1); 3 . Five hybrids $J$. thurifera $\mathrm{x} J$. sabina var. sabina (Type 2) (referred as thu x sabT2) (orange, Table 1); 4. Fifteen hybrids, J. thurifera $\mathrm{x} J$. sabina var. sabina (Type 1) (referred as thu $\mathrm{x}$ sabT1) (blue, Table 1); 5. Nine homoploid J. sabina hybrids between the Type 1 and the Type 2 (referred as sab T1xT2) (yellow, Table 1). In addition, two plants 15646 and 15774 seem to be probably hybrids between individuals of group 3 and 4 . It should be noted that pure J. sabina var. sabina, Type 2 haplotype (sabT2) was not found among these samples (Table 1, bottom). However, because the T2 haplotype is present in the sab $\mathrm{T} 1 \times \mathrm{x} 2$ and thu $\mathrm{x}$ sabT2 samples, this implies that J. sabina var. sabina (Type 2) is present in the population or nearby, even though we did not collect it in this study.

Principle Coordinates Ordination (PCOR) of the ITS data was conducted by coding the presence / absence of each allele to produce a similarity matrix among the samples. Factoring the matrix resulted in four eigenroots before asymptoting [20]. This supports the presence of five groups (\# eigenroots +1 ), as seen in Table 1 with the two hybrids 15646 (46) and 15774 (74) are loosely grouped with other hybrids (Fig. 2 a, b). Coordinate axis 1 (PCOR 1) separated J. sabina var. sabina from $J$. thurifera (Fig. 2a, b). The hybrids, thu $\mathrm{x}$ sabT1, ordinate in an intermediate position on PCOR 1 between the parents, while the PCOR 2 ordinates the hybrids as a third entity (I.e., J. thurifera, J. sabina and hybrids). Thus, the 2D ordination produces the $\mathrm{U}$ or $\mathrm{V}$ shape commonly found in the analyses of synthetic and natural hybridization [21, 22]. The five hybrids putative (thu $\mathrm{x}$ sabT2) are near the position of the hybrids thu $\mathrm{x}$ sabT1 between J. sabina and J. thurifera on the PCOR1. Notice that the samples 15646 (46) and 15774 (74) are located between the hybrids thu $\mathrm{x}$ sabT1 and thu $\mathrm{x}$ sabT2. Those two individuals are putative hybrids between those two groups as shown in the Table 1.

Juniperus sabina var. sabina (T1) and J. sabina var. sabina hybrids (T1xT2) are resolved on coordinate axis 3 (12\% of the variation, Fig. $2 b)$.

Dynamics between J. sabina var. sabina and J. sabina var. balkanensis in a population in the Sierra de Baza: gene flow from distant, allopatric J. thurifera

Analyses of trnS-G (cp DNA) confirmed that all the tetraploids found in this population have cpDNA of the $J$. thurifera (=cpDNA of $J$. sabina var. balkanensis) Type (Table 2).

ITS sequences of three J. sabina var. sabina and two J. sabina var. balkanensis as well as two J. thurifera samples were included in the analyses (shaded in gold, Table 2) and 29 informative sites were discovered. Both Types 1 and 2 ITS sequences were found in the population (Table 2), with the majority of plants being Type 1 , similar to that reported in other regions [15-17]. Of the non-hybrid plants, three J. sabina var. sabina were Type 2 (T2), and six were Type 1 (T1). Of J. sabina var. balkanensis plants, none were Type 2, but three were Type 1 (Table 2).

Based on ploidy, cpDNA (trnS-G) and ITS sequences, the 30 samples could be divided into five groups: $1 . J$. sabina var. sabina (T2) (sabT2) (yellow, Table 2); 2. J. sabina var. balkanensis (T1) (balkT1) (pink, Table 2); 3. J. sabina var. sabina (T1) (sabT1) (blue, Table 2); 4. J. sabina var. balkanensis (T1) x J. thurifera putative hybrids (referred as balkT1 $\mathrm{x}$ thu) (salmon-beige, Table 2); and 5. Putative J. sabina var. balkanensis (T1) x J. thurifera hybrids, backcrossed to J. thurifera (referred as balk-(BC-thu)) (red, Table 2).

It is obvious that the hybrids are rather variable, and it seems likely that some of these are $F_{2}$ progeny. Many of $J$. sabina var. sabina plants have one or more sites that reflects past hybridizations between the ITS Types (1 and 2).

Factoring the Sierra de Baza plants ITS data matrix (based on 29 SNPs) resulted in five eigenroots that accounted for 49.20, 19.22, 11.35, 4.78 and $4.10 \%$ (88.63\% total) of the variance among samples. PCOR 
Table 1 Informative SNPs (21) from Eastern Iberian Range populations. Sites in row one in yellow distinguish Type 1 (T1) and Type 2 (T2) ITS in J. sabina (sab) and sites in green distinguish J. thurifera (thu) and J. sabina.

\begin{tabular}{|c|c|c|c|c|c|c|c|c|c|c|c|c|c|c|c|c|c|c|c|c|c|c|c|c|c|}
\hline $\begin{array}{l}\text { Sample \#, } \\
\text { Field ID }\end{array}$ & poly. sites/ taxon & ср Туре & & & & & & & . & 总. & $\stackrel{\infty}{\infty}$, & & 粂* & 管+ & $\tilde{\sigma}+$ & & $\bar{\delta}+$ & $\widetilde{\widetilde{\infty}}+$ & $\stackrel{\circ}{2} *$ & 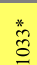 & $\stackrel{*}{*}$ & 寺 & 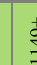 & & 吉 \\
\hline 15616 thu & thu & thu & $4 x$ & & A & C & A & C & G & $\mathrm{T}$ & G & C & G & G & $\mathrm{T}$ & G & $\mathrm{T}$ & A & C & G & G & A & & & \\
\hline $\begin{array}{l}15617 \text { thu } \\
15618 \text { thum }\end{array}$ & & thu & $4 x$ & T & A & C & A & C & G & $\mathrm{T}$ & G & C & G & G & ${ }_{T}^{T}$ & C & ${ }_{T}^{T}$ & $\mathrm{~A}$ & C & G & & & & & \\
\hline 15619 thu & $\begin{array}{l}\text { nnu } \\
\text { thu }\end{array}$ & $\begin{array}{l}\text { thu } \\
\text { thu }\end{array}$ & $4 x$ & $T$ & A & C & A & $\mathrm{C}$ & G & $T$ & $\begin{array}{l}G \\
G\end{array}$ & ${ }_{\mathrm{C}}^{\mathrm{C}}$ & $\begin{array}{l}G \\
G\end{array}$ & G & $T$ & G & $T$ & A & C & $\begin{array}{l}\mathrm{G} \\
\mathrm{G}\end{array}$ & G & & & & $\begin{array}{l}\mathrm{A} \\
\mathrm{A}\end{array}$ \\
\hline 15620 thu & thu & thu & $4 x$ & $\mathrm{~T}$ & A & $\mathrm{C}$ & A & $\mathrm{C}$ & G & $\mathrm{T}$ & G & $\mathrm{C}$ & G & G & $\mathrm{T}$ & G & $\mathrm{T}$ & A & $\mathrm{C}$ & G & G & & & & \\
\hline 15621 thu & thu & thu & $4 x$ & $\mathrm{~T}$ & A & C & A & C & G & $\mathrm{T}$ & G & C & G & G & $T$ & G & $T$ & A & $\mathrm{C}$ & G & G & & & & \\
\hline 15622 thu & thu & thu & $4 x$ & $T$ & A & C & A & C & G & $T$ & G & $\mathrm{C}$ & G & G & $\mathrm{T}$ & G & $\mathrm{T}$ & A & C & G & G & & & & \\
\hline 15623 thu & thu & thu & $4 x$ & $\mathrm{~T}$ & A & $\mathrm{C}$ & A & $\mathrm{C}$ & G & $T$ & G & $\mathrm{C}$ & $\mathrm{G}$ & G & $\mathrm{T}$ & G & $\mathrm{T}$ & A & $\mathrm{C}$ & G & $\mathrm{G}$ & & & & \\
\hline $\begin{array}{l}15624 \text { thu } \\
15625 \text { thu }\end{array}$ & thu & thu & $4 x$ & $T$ & A & C & A & C & G & $T$ & G & C & G & G & $T$ & G & $T$ & A & C & G & G & & & & \\
\hline $\begin{array}{l}15625 \text { thu } \\
1568 \mathrm{SxT}\end{array}$ & $\begin{array}{l}\text { thu } \\
\text { thu } x \text { sabT2 }\end{array}$ & $\begin{array}{l}\text { thu } \\
\text { thu }\end{array}$ & $3 x$ & $\begin{array}{l}1 \\
Y \\
\end{array}$ & M & & $\begin{array}{l}\mathrm{A} \\
\mathrm{A}\end{array}$ & & G & $\mathrm{Y}$ & S & & $\begin{array}{l}\mathrm{G} \\
\mathrm{G}\end{array}$ & $\begin{array}{l}G \\
G\end{array}$ & $\mathrm{Y}$ & $\mathrm{G}_{\mathrm{G}}$ & $\mathrm{Y}$ & $\begin{array}{l}\mathrm{A} \\
\mathrm{R}\end{array}$ & M & $\begin{array}{l}G \\
G\end{array}$ & & & & & \\
\hline $15766 \mathrm{SxT}$ & thu $x$ sabT2 & thu & $3 x$ & $\mathrm{Y}$ & $\mathrm{M}$ & $\mathrm{Y}$ & A & $\mathrm{Y}$ & $\mathrm{R}$ & $\mathrm{Y}$ & $\mathrm{S}$ & $\mathrm{Y}$ & G & G & $\mathrm{Y}$ & G & $\mathrm{Y}$ & $\mathrm{R}$ & $\mathrm{M}$ & G & $\mathrm{K}$ & $\mathrm{R}$ & & & \\
\hline $15767 \mathrm{SxT}$ & thu $x$ sab & thu & $3 x$ & Y & M & Y & A & $\mathrm{Y}$ & $\mathrm{R}$ & $\mathrm{Y}$ & $\mathrm{S}$ & $\mathrm{Y}$ & G & G & Y & G & Y & $\mathrm{R}$ & M & G & $\mathrm{K}$ & $\mathrm{R}$ & & & \\
\hline $\begin{array}{l}15769 \mathrm{ST} \\
15771 \mathrm{SxT}\end{array}$ & thu x sab & thu & $3 x$ & $\frac{Y}{Y}$ & $\mathrm{M}$ & $\begin{array}{l}\mathrm{Y} \\
\mathrm{Y}\end{array}$ & A & $\begin{array}{l}\mathrm{Y} \\
\mathrm{Y}\end{array}$ & $\frac{\mathrm{R}}{\mathrm{R}}$ & $\begin{array}{l}\mathrm{Y} \\
\mathrm{Y}\end{array}$ & $\frac{\mathrm{s}}{\mathrm{s}}$ & $\frac{Y}{Y}$ & G & G & $\begin{array}{l}\mathrm{Y} \\
\mathrm{Y}\end{array}$ & $\mathrm{G}$ & $\begin{array}{l}\mathrm{Y} \\
\mathrm{Y}\end{array}$ & $\mathrm{R}$ & $\mathrm{M}$ & G & $\frac{\mathrm{K}}{\mathrm{K}}$ & & & & \\
\hline $15646 \mathrm{SxT}$ & (thu $x$ sabT2) & $\begin{array}{l}\text { nut } \\
\text { thu }\end{array}$ & $\frac{3 x}{3 x}$ & $\begin{array}{l}Y \\
Y\end{array}$ & $M$ & $\begin{array}{l}Y \\
Y\end{array}$ & A & $\begin{array}{l}\mathrm{Y} \\
\mathrm{Y}\end{array}$ & $\frac{K}{R}$ & $\begin{array}{l}Y \\
Y\end{array}$ & $\frac{S}{S}$ & & G & $\frac{G}{N}$ & $\frac{Y}{Y}$ & & $\frac{Y}{Y}$ & $\frac{K}{R}$ & $\frac{M}{M}$ & & $\mathrm{~K}$ & & & & \\
\hline $15774 \mathrm{SxT}$ & (thu x sabT1) & thu & $3 x$ & $\begin{array}{rlll}\mathrm{Y} & 0 \\
\end{array}$ & $\mathrm{M}$ & $\begin{array}{lll}\mathrm{Y} & 0 \\
\end{array}$ & $\mathrm{R}$ & 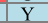 & $\mathrm{R}$ & $\mathrm{Y}$ & $\mathrm{s}$ & $\mathrm{y}$ & $R_{R}$ & $\mathrm{G}$ & $\mathrm{Y}$ & & $\mathrm{Y}$ & $\mathrm{R}$ & M & R & $\mathrm{K}$ & & & & \\
\hline $15647 \mathrm{SxT}$ & thu $x$ sabTl & thu & $3 x$ & $\mathrm{Y}$ & $M$ & $\mathrm{Y}$ & $\mathrm{R}$ & & $R$ & $\mathrm{Y}$ & $\mathrm{G}$ & & $R_{R}$ & K & $\mathrm{Y}$ & & $\mathrm{Y}$ & $R_{R}$ & $\mathrm{C}$ & $R_{R}$ & $\mathrm{G}$ & & & & \\
\hline $15648 \mathrm{SxT}$ & thu $x$ sabT1 & thu & $3 x$ & $\dot{Y}$ & $\mathrm{M}$ & $\begin{aligned} \mathrm{Y} \\
\end{aligned}$ & $R$ & $Y$ & $R$ & Y & G & & $R$ & $\mathrm{~K}$ & Y & & Y & 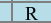 & C & $R_{R}$ & G & & & & $\mathrm{M}$ \\
\hline $15649 \mathrm{SxT}$ & thu $x$ & hu & $3 x$ & 1 & M & $Y$ & $R$ & & R & $\mathrm{Y}$ & G & & R & K & $\mathrm{Y}$ & & $\mathrm{Y}$ & $R$ & $\mathrm{C}$ & $\mathrm{R}$ & G & $\mathrm{R}$ & & & \\
\hline 3. SxT & & thu & $3 x$ & Y & M & Y & $\mathrm{R}$ & & R & $\mathrm{Y}$ & G & & $\mathrm{R}$ & N & Y & & $\mathrm{Y}$ & $\mathrm{R}$ & $\mathrm{C}$ & $R$ & G & $\mathrm{R}$ & & & \\
\hline$\frac{1565}{1565}$ & & thu & $3 x$ & $\begin{array}{r}Y \\
Y \\
Y\end{array}$ & $\mathrm{M}$ & $\begin{array}{l}\mathrm{Y} \\
\mathrm{Y}\end{array}$ & $\frac{R}{R}$ & $\frac{Y}{Y}$ & $\frac{R}{R}$ & $\frac{\mathrm{Y}}{\mathrm{Y}}$ & G & $\mathrm{Y}$ & $\frac{R}{R}$ & K & $\begin{array}{l}\mathrm{Y} \\
\mathrm{Y}\end{array}$ & $K$ & $\begin{array}{l}\mathrm{Y} \\
\mathrm{Y}\end{array}$ & $\mathrm{R}$ & C & $\frac{R}{R}$ & G & $\mathrm{R}$ & & & $\mathrm{M}$ \\
\hline $15651 \mathrm{SxT}$ & & thu & $\frac{3 x}{3 x}$ & $\mathrm{Y}$ & $\mathrm{M}$ & $\mathrm{Y}$ & $\mathrm{R}$ & $\mathrm{Y}$ & $\mathrm{R}$ & $\mathrm{Y}$ & G & $\mathrm{Y}$ & $\mathrm{R}$ & $\mathrm{K}$ & $\mathrm{Y}$ & $\mathrm{K}$ & $\mathrm{Y}$ & $\mathrm{R}$ & $\mathrm{C}$ & $\mathrm{R}$ & G & & & & \\
\hline $15652 \mathrm{SxT}$ & thu $\times \mathrm{s}$. & thu & $3 x$ & $\mathrm{Y}$ & M & $\mathrm{Y}$ & $\mathrm{R}$ & $\mathrm{Y}$ & $\mathrm{R}$ & $\mathrm{Y}$ & G & $\mathrm{Y}$ & $\mathrm{R}$ & $\mathrm{K}$ & $\mathrm{Y}$ & $\mathrm{K}$ & $\mathrm{Y}$ & $\mathrm{R}$ & $\mathrm{C}$ & $\mathrm{R}$ & G & & & & \\
\hline $15655 \mathrm{SxT}$ & thu $\times$ s: & thu & $3 x$ & $Y$ & M & $\mathrm{Y}$ & $\mathrm{R}$ & Y & $\mathrm{R}$ & Y & G & Y & $\mathrm{R}$ & $\mathrm{K}$ & $Y$ & K & $Y$ & $\mathrm{R}$ & $\mathrm{C}$ & $\mathrm{R}$ & G & $\mathrm{R}$ & & & \\
\hline $\begin{array}{l}\text { SxT } \\
\text { SxT }\end{array}$ & thu X sa & $\begin{array}{l}\text { thu } \\
\text { thun }\end{array}$ & $\frac{3 x}{3 x}$ & $\begin{array}{l}\mathrm{Y} \\
\mathrm{Y}\end{array}$ & M & $\frac{\mathrm{Y}}{\mathrm{Y}}$ & $\mathrm{R}$ & $\mathrm{Y}$ & $\frac{R}{R}$ & $\begin{array}{l}\mathrm{Y} \\
\mathrm{Y}\end{array}$ & G & $\mathrm{Y}$ & R & K & $\mathrm{Y}$ & K & $\mathrm{Y}$ & $\mathrm{R}$ & $\mathrm{C}$ & $\mathrm{R}$ & $\mathrm{G}$ & & & & $\mathrm{M}$ \\
\hline & & & $\frac{3 x}{3 x}$ & & & & $\frac{\mathrm{K}}{\mathrm{R}}$ & & $\frac{K}{R}$ & & $\begin{array}{l}\text { G } \\
G\end{array}$ & & $\frac{\mathrm{K}}{\mathrm{R}}$ & & $\mathrm{Y}$ & & & $\mathrm{R}$ & & $\begin{array}{r}\mathrm{R} \\
\mathrm{R}\end{array}$ & & & & & \\
\hline $15770 \mathrm{SxT}$ & & the & $3 x$ & & $\mathrm{M}$ & & $\frac{R}{R}$ & & $R_{R}$ & $\mathrm{Y}$ & $\mathrm{G}$ & & $R_{R}$ & & $\mathrm{Y}$ & & $\mathrm{Y}$ & R & $\mathrm{C}$ & $\mathrm{R}$ & G & $\mathrm{R}$ & & & \\
\hline $15772 \mathrm{SxT}$ & & th & $3 x$ & & M & & $\mathrm{R}$ & & $\mathrm{R}$ & $\bar{Y}$ & G & & $\mathrm{R}$ & & $\begin{array}{l} \\
Y\end{array}$ & & Y & $\mathrm{R}$ & $\mathrm{C}$ & R & G & & & & \\
\hline $15773 \mathrm{SxT}$ & & th & $3 x$ & $\begin{array}{lll}\mathrm{Y} & & \end{array}$ & $\mathrm{M}$ & $\begin{array}{cccc}\mathrm{Y} & & \end{array}$ & R & & $\begin{array}{ll}\mathrm{R} \\
\mathrm{R}\end{array}$ & $\mathrm{Y}$ & G & & $\mathrm{R}$ & & $\begin{array}{r}Y \\
Y\end{array}$ & & $\begin{array}{llll}\mathrm{Y} & & \end{array}$ & $\mathrm{G}$ & $\mathrm{C}$ & $\mathrm{R}$ & G & $\bar{R}$ & & & M \\
\hline & sa & sab & $2 x$ & $\mathrm{C}$ & C & $T$ & $\mathrm{G}$ & & $\mathrm{A}$ & $\mathrm{C}$ & G & & & 1 & $\mathrm{C}$ & & $\mathrm{C}$ & G & $\mathrm{C}$ & A & $\mathrm{G}$ & & & & $\mathrm{C}$ \\
\hline & & $\mathrm{sab}$ & $2 x$ & C & C & $T$ & G & $T$ & A & C & G & & A & 1 & C & & C & G & C & A & G & & & & \\
\hline $15633 \mathrm{sab}$ & & sab & $2 x$ & C & C & $T$ & G & $T$ & A & C & G & $T$ & A & $T$ & C & $T$ & $\mathrm{C}$ & G & C & A & G & G & & & C \\
\hline & & sab & $2 x$ & $\mathrm{C}$ & $\mathrm{C}$ & $\frac{T}{T}$ & G & $\frac{T}{T}$ & A & $\mathrm{C}$ & G & T & A & T & $\mathrm{C}$ & & $\mathrm{C}$ & G & $\mathrm{C}$ & A & $\mathrm{G}$ & & & & $\mathrm{C}$ \\
\hline & & sab & $\frac{2 x}{2 x}$ & $\mathrm{C}_{\mathrm{C}}$ & $\mathrm{C}$ & $T$ & G & $T$ & A & C & G & $T$ & A & $T^{2}$ & C & $T$ & $\mathrm{C}$ & G & $C$ & A & G & & & & C \\
\hline $15638 \mathrm{sab}$ & & sab & $2 x$ & $\mathrm{C}$ & C & $\mathrm{T}$ & G & $\mathrm{T}$ & A & $\mathrm{C}$ & $\mathrm{G}$ & $T$ & A & $\mathrm{T}$ & $\mathrm{C}$ & $\mathrm{T}$ & C & G & $\mathrm{C}$ & A & $\mathrm{G}$ & G & & & \\
\hline & & sa & $2 x$ & C & C & $T$ & G & $T$ & A & C & G & $T$ & A & $T$ & C & $T$ & C & G & C & A & G & G & & & \\
\hline & & sab & $2 x$ & C & C & $T$ & G & $T$ & A & C & G & $T$ & A & $T$ & $\mathrm{C}$ & $T$ & $\mathrm{C}$ & G & $\mathrm{C}$ & A & G & G & & & \\
\hline & & sab & $\frac{2 x}{2 x}$ & c & $\mathrm{C}$ & $\frac{1}{T}$ & G & & A & $\mathrm{C}$ & $\mathrm{G}$ & & A & & C & & C & G & $\mathrm{C}$ & & G & & & & \\
\hline 1562 & sab T1 $\times$ T-2 & sab & $2 x$ & $\mathrm{C}$ & $\mathrm{C}$ & $T$ & $\mathrm{R}$ & $\mathrm{T}$ & A & $\mathrm{C}$ & S & $T$ & $\mathrm{R}$ & $\mathrm{K}$ & $\mathrm{C}$ & $T$ & $\mathrm{C}$ & G & M & $\mathrm{R}$ & $\mathrm{K}$ & G & & & \\
\hline$\frac{15629 \mathrm{sab}}{15630 \mathrm{sh}}$ & sab T1 $\times$ T- & sab & $2 x$ & $\mathrm{C}$ & $\mathrm{C}$ & $\frac{T}{T}$ & $\mathrm{R}$ & $T$ & A & $\mathrm{C}$ & S & $T$ & $\mathrm{R}$ & K & $\mathrm{C}$ & $\frac{T}{T}$ & $\mathrm{C}$ & G & $M$ & $\mathrm{R}$ & K & G & & & $\frac{\mathrm{C}}{\mathrm{C}}$ \\
\hline $\begin{array}{l}15630 \mathrm{sab} \\
1563 \mathrm{sab}\end{array}$ & $\begin{array}{l}\text { sab T1 x T2 } \\
\text { sab T1 }\end{array}$ & sab & $2 x$ & & C & & R & & A & & $\frac{\mathrm{S}}{\mathrm{s}}$ & & $\frac{R}{R}$ & & $\frac{C}{C}$ & $\frac{T}{T}$ & C & G & $\mathrm{M}$ & $\mathrm{R}$ & $\frac{\mathrm{K}}{K}$ & G & & & $\frac{\mathrm{C}}{\mathrm{C}}$ \\
\hline$\frac{15031 \mathrm{~s}}{15632 \mathrm{~s}}$ & & sab & $\frac{2 x}{2 x}$ & C & $\mathrm{C}$ & $T$ & $\mathrm{R}$ & T & A & $\mathrm{C}$ & $\frac{2}{3}$ & $\frac{1}{T}$ & $\mathrm{R}$ & $\mathrm{K}$ & $\mathrm{C}$ & $\frac{1}{T}$ & $\mathrm{C}$ & G & $M$ & $\mathrm{R}$ & $\frac{\mathrm{N}}{\mathrm{K}}$ & $\mathrm{G}$ & & & $\mathrm{C}$ \\
\hline $15637 \mathrm{sab}$ & & sab & $2 x$ & 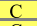 & $\mathrm{C}$ & 1 & $\mathrm{R}$ & $T$ & A & $\mathrm{C}$ & $\mathrm{S}$ & $T$ & $\mathrm{R}$ & K & $\mathrm{C}$ & $T$ & $\mathrm{C}$ & G & M & $\mathrm{R}$ & K & $\mathrm{G}$ & & & \\
\hline & & sab & $2 x$ & & $\mathrm{C}$ & & $\frac{R}{R}$ & T & A & $\mathrm{C}$ & & $\frac{T}{T}$ & $\mathrm{R}$ & K & $\mathrm{C}$ & $\frac{T}{T}$ & $\mathrm{C}$ & G & $\mathrm{M}$ & $\frac{R}{P}$ & K & G & & - & $\mathrm{C}$ \\
\hline & $\frac{5 \mathrm{sab} T 1 \times \mathrm{T}-2}{\mathrm{sab} \mathrm{Tl} \times \mathrm{T}-2}$ & $\begin{array}{l}\text { sao } \\
\text { sab }\end{array}$ & $2 x$ & & & & & & A & & & & $\mathrm{R}$ & & & & & & & & $K^{k}$ & G & & & \\
\hline sab Tvpe 1 & & & & C & $\mathrm{C}$ & & G & & A & $\mathrm{C}$ & $\mathrm{G}$ & & A & $T$ & $\mathrm{C}$ & & $\mathrm{C}$ & G & $\mathrm{C}$ & A & G & G & & & $\mathrm{C}$ \\
\hline sab Tvpe 2 & $\begin{array}{l}\text { Ref(not found) } \\
\text { Reference }\end{array}$ & & & & $\mathrm{C}$ & $T$ & A & & & $\mathrm{C}$ & 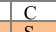 & $\frac{T}{T}$ & G & G & C & G & $\mathrm{C}$ & G & $\mathrm{A}$ & $\mathrm{P}$ & & & & & \\
\hline sab Tlx & Reference & & & $\mathrm{C}$ & $\mathrm{C}$ & $\mathrm{T}$ & & & A & & $\mathrm{S}$ & & $\mathrm{R}$ & & & $\mathrm{K}$ & $\mathrm{C}$ & G & M & $\mathrm{R}$ & K & & & & \\
\hline
\end{tabular}

ordination using the first three coordinates reveals (Fig. 3) the first axis primarily resolved J. sabina (i.e., both $J$. sabina var. balkanensis and J. sabina var. sabina) from the reference J. thurifera (thu) samples and partially resolved J. sabina var. balkanensis $\mathrm{x} J$. thurifera hybrids (balkT1 $\mathrm{x}$ thu, $4 x$ ) into two groups (Fig. $3)$. The difference between the (15681 (81), 15686 (86), 15690 (90)) group and the larger group of hybrids is readily seen in Table 2 , as 81,86 , and 90 share several SNPs (note sites 389, 543, 802, 1033) that differ from the other hybrids. Sample 63 (15663) is likely $\mathrm{F}_{2}$ generation plant (note the variation among SNPs, Table 2). All of $J$. sabina var. sabina, Types 1 (sabT1, 2x) and 2 (sabT2, 2x), along with J. sabina var. balkanensis Type 1 (balkT1, $4 x$ ), are ordinated on the left (Fig. 3), but coordinate axis 2 resolves these groups. Axis 3 serves to separate individuals and partially resolve the (sabT $1,2 x)$ group (blue, Fig. 3 ). It should be noted that J. sabina var. balkanensis backcrosses to J. thurifera (balk-(BC-thu)) group (Fig. 3) are ordinated near to the reference $J$. thurifera (thu) samples, indicative of their backcross nature.
The examination of hybridization by the use of all 29 SNPs is hindered by the inclusion of the 8 SNPs that distinguish J. sabina Types 1 and 2 ITS sequences. The 8 SNPs plus 4 with low information content (12 SNPs total) were removed (compare Tables 2, 3) and the data set was re-run using 17 informative SNPs. Factoring the similarity matrix yielded four eigenroots before the roots asymptoted. These four eigenroots accounted for 65, 15.19, 7 and $4.05 \%$ (90.54\%) of the variance among the samples. It should be mentioned that the variance accounted for is now much larger on axis $1,49 \%$ vs. $65 \%$; with a reduction on axis $2: 19 \%$ vs. $15 \%$; and axis $3: 11 \%$ vs. $7 \%$.

Ordination revealed that axis 1 clearly separates the two varieties of J. sabina from $J$. thurifera reference samples, and from J. sabina var. balkanensis x J. thurifera hybrids (balkT1 $\mathrm{x}$ thu, 4x) (Fig. 4). The hybrids now form a tighter group, but with some variation that is likely due to the presence of $F_{2}$ generation individuals. Notice that the ITS sequence of J. sabina var. balkanensis Type 1 (balkT1, 4x) places it in association with $J$. sabina var. sabina Types 1 and 2 (Fig. 4). In fact, it is essentially unresolved by these 17 SNPs from J. sabina var. 

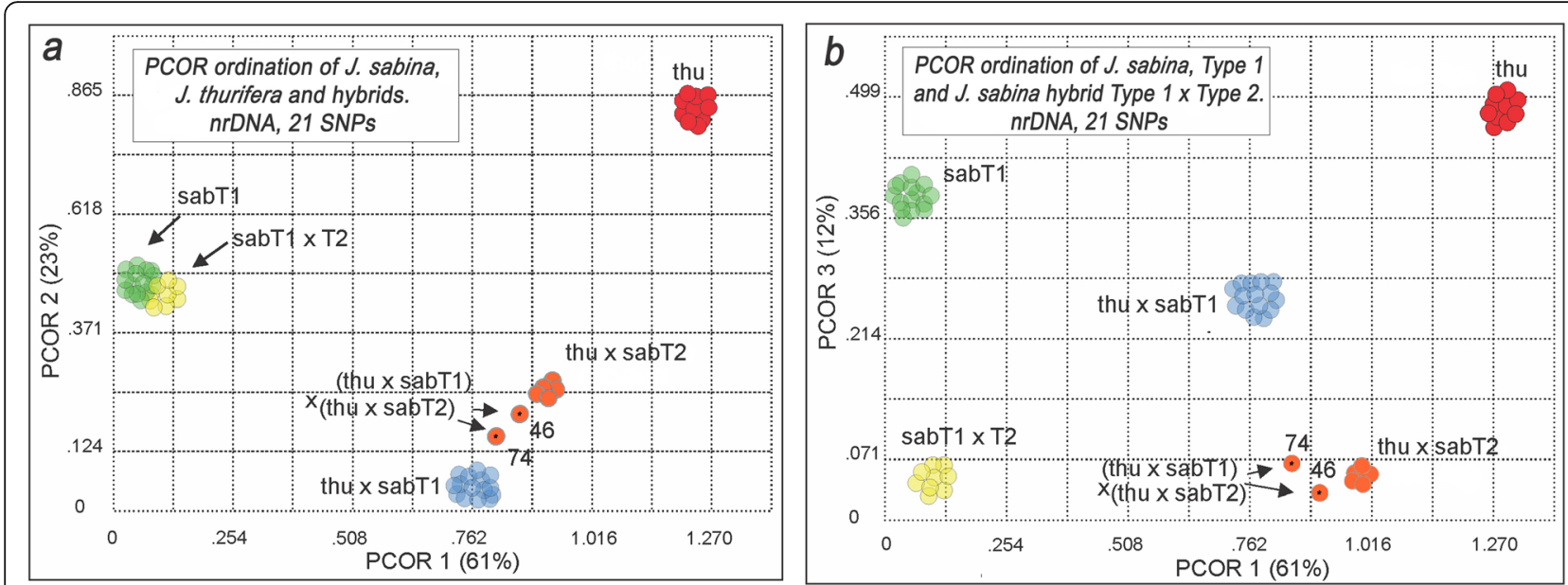

Fig. 2 PCOR of Juniperus studied taxa from Eastern Iberian Range using 21 SNPs of nrDNA data. This PCOR includes $10 \mathrm{~J}$. thurifera, $20 \mathrm{~J}$. sabina var. sabina, and 22 putative hybrids. Colors correspond to Table 1

Table 2 Informative SNPS (29) in the Sierra de Baza population. In row one, sites in yellow are informative about Type 1 or Type 2 ITS and sites in green and with a + are informative about hybridization between J. sabina and J. thurifera; sites with no color shading are not clearly informative or not scored (N). Several reference samples (in gold shading sample ID) are included: S3 14316 (sabT2); B2 14723 (balkT2); B1 14934 (balkT1); S1 7573 (sabT1); S2 15628 (sabT1); T1 15616 (thu); T2 15617 (thu).

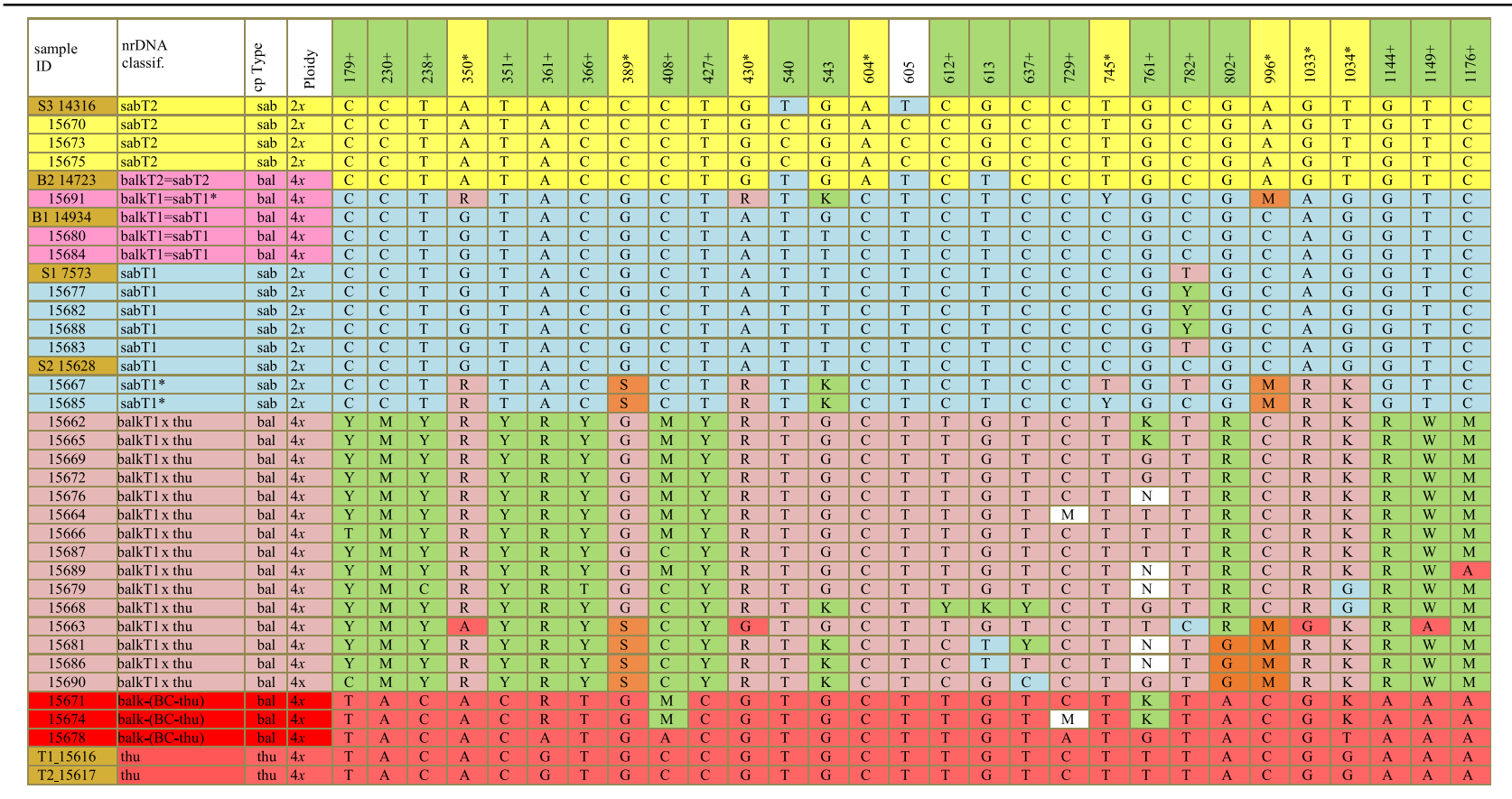

Abbreviations

bal, balk: J. sabina var. balkanensis, sab: J. sabina var. sabina, thu: J. thurifera, BC Back cross, SxT: hybrid, J. sabina $\mathrm{x}$ J. thurifera

29 Poly. Sites locations:

1 (179), 2(230), 3(238), 4(350), 5(351), 6(361), 7(366), 8(389), 9(408), 10(427), 11(430), 12(540), 13(543), 14(604), 15(605), 16(612), 17(613), 18(637), 19(729), 20(745), 21(761), 22(782), 23(802), 24(996), 25(1033), 26(1034), 27(1144), 28(1149), 29(1176). 801 poor skipped. 


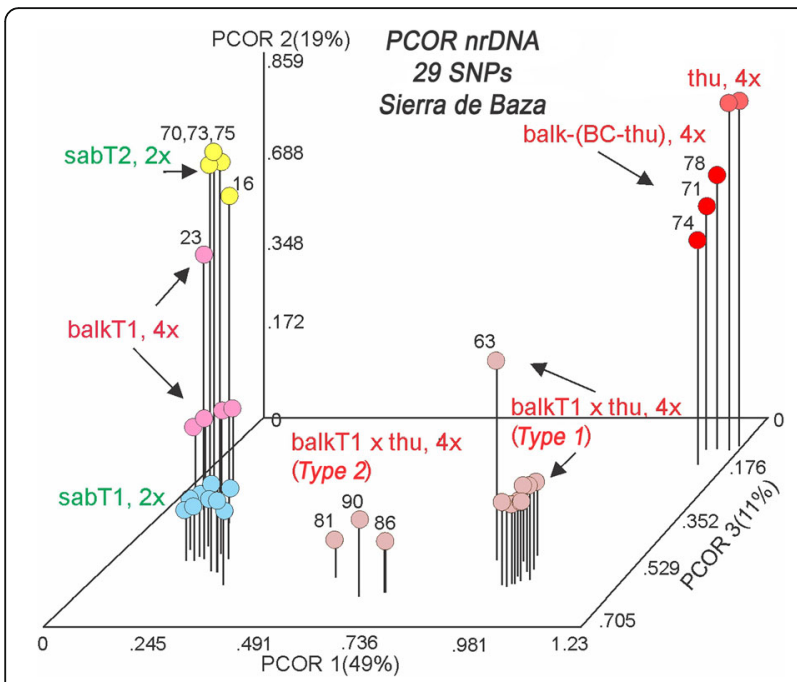

Fig. 3 PCOR of Juniperus studied taxa from Sierra de Baza using 29 SNPs of nrDNA data. The PCOR ordination includes $30 \mathrm{~J}$. sabina var. sabina and $J$. sabina var. balkanensis plus two reference $J$. thurifera samples. The group colors correspond to Table 2

sabina. The full ITS (1270 bp) sequence provides only minor resolution between J. sabina var. sabina and J. sabina var. balkanensis (ddRAD sequencing has provided resolution, but small, between the varieties, manuscript in preparation, RPA).

Individual 63 (15663, Table 2) is an oddity in its loose grouping and in it several anomalous SNPs (Table 2). It may be an usual $\mathrm{F}_{2}$ or a backcross plant.

\section{Discussion}

\section{Ploidy levels}

Despite the rarity of polyploidy in conifers, a highly interesting spectrum of ploidy levels has been recently shown in wild populations of Juniperus genus $(2 n=2 x$, $2 n=4 x$ and $2 n=6 x)$ [7, 16]. This makes polyploidy an important evolutionary mechanism which was implicated at least 10 times during Juniperus evolution [7]. The ploidy levels of the taxa in this study except for the potential hybrid trees were previously published $[7,16$, 23, 24]. However, intra-specific variation in the ploidy level has been reported in this genus notably in J. sabina, J. chinensis L., and J. seravschanica Kom., [7, 16, 23-25] which makes essential the ploidy level determination of the studied populations.

In Juniperus, it has been shown that ploidy level can be inferred from genome size [7]. Based on this inference, in the E Iberian Range, all studied individuals of $J$. thurifera and J. sabina var. sabina were found to be tetraploid $(2 n=4 x)$ and diploid $(2 n=2 x)$, respectively. Genome sizes of the 22 putative hybrids (Juniperus $x$ cerropastorensis) were intermediate between the ranges of GS defined for diploid and tetraploid levels.
Therefore, those putative hybrids appear to be triploids $(2 n=3 x)$. Despite the fact that triploids are usually unstable and sterile, they are an important pathway "triploid-bridge" for reaching a stable ploidy level [26]. In a general context, many pathways were suggested to achieve a triploid stage such as polyspermy and unreduced gamete $[27,28]$. In the present study, a fertilization between a diploid gamete $(n=2 x)$ produced normally by the tetraploid $J$. thurifera and a haploid gamete from the diploid J. sabina var. sabina will produce a triploid progeny.

Recently, the first three Juniperus triploid hybrids between $J$. thurifera and J. sabina var. sabina have been identified in the wild in the French Alps [18]. It suggests that when J. thurifera and J. sabina var. sabina co-occur in the same geographical zone they may hybridize generating triploid hybrids.

In the Sierra de Baza site, containing J. sabina var. sabina and J. sabina var. balkanensis, approximately two-thirds of the shrubs showed a mean GS indicative of a tetraploid and just one-third had a GS at the diploid level. In this site, no triploids were found. Despite that J. sabina var. sabina and J. sabina var. balkanensis can scarcely be identified in the field, two criteria do separate those two taxa. The first criterion is that J. sabina var. balkanensis has the chloroplast sequences of $J$. thurifera $[15,17,29]$. The second criterion is, at present, all populations studied of $J$. sabina var. sabina and J. sabina var. balkanensis have been shown to be diploid and tetraploid, respectively [16]. This suggests, based on ploidy data, that $2 / 3$ of the individuals in the Sierra de Baza population are possibly $J$. sabina var. balkanensis and $1 / 3$ are probably $J$. sabina var. sabina.

\section{Homoploid and heteroploid hybridization in Eastern Iberian Range populations}

The importance of interspecific hybridization as a driver for plant evolution has been debated for decades [30-33]. Lately, the significance of this phenomenon in plant speciation and evolution has been well defended [34, 35]. The usage of nrDNA (especially ITS region) to detect hybrids has been widely implemented in plant studies due to its remarkable proprieties; we mention the homogenous paralogs within individuals as a result of concerted evolution $[36,37]$. As well, this marker was highly explored in nearly all Juniperus taxa (including haplotypes within taxa) for phylogenetic purposes and showed high efficiency in junipers hybridization studies with relatively good number of informative SNPs [5, 6, 8, 10, 11, 15, $17,21,29]$. In this study, we found two categories of hybrids, homoploid and heteroploid hybrids. Homoploid hybrids $(2 n=2 x)$ were found between the two 
Table 3 Reduced character set of 17 informative SNPs in the Sierra de Baza population. SNPs that distinguish Type 1 and 2 ITS, as well as ambiguous SNPs have been removed. Notice the uniformity of J. sabina var. sabina, Type 2 (sabT2), J. sabina var. balkanensis, Type 1 and 2 (balkT1, balkT2) groups and J. sabina var. sabina Type 1 (sabT1), except for site 782, which is very near the indel at 801.

\begin{tabular}{|c|c|c|c|c|c|c|c|c|c|c|c|c|c|c|c|c|c|c|c|c|}
\hline $\begin{array}{l}\text { sample } \\
\text { ID }\end{array}$ & $\begin{array}{l}\text { nrDNA } \\
\text { classif. }\end{array}$ & 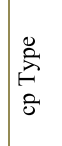 & $\frac{2}{0}$ & $\stackrel{+}{a}$ & స్ & 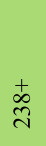 & $\frac{t}{n}$ & $\frac{ \pm}{0}$ & 圅 & $\begin{array}{c}+ \\
\stackrel{+}{+} \\
+\end{array}$ & $\stackrel{+}{\stackrel{+}{y}}$ & $\underset{\mathrm{\sigma}}{+}$ & $\frac{+}{6}$ & ते & $\frac{1}{2}$ & $\stackrel{+}{\infty}$ & さั่ & $\stackrel{+}{\stackrel{+}{J}}$ & $\stackrel{+}{\stackrel{+}{J}}$ & $\stackrel{t}{\stackrel{5}{\Xi}}$ \\
\hline S3 14316 & sabT2 & sab & $2 x$ & $\mathrm{C}$ & $\mathrm{C}$ & $\mathrm{T}$ & $\mathrm{T}$ & A & $\mathrm{C}$ & $\mathrm{C}$ & $\mathrm{T}$ & $\mathrm{C}$ & $\mathrm{C}$ & $\mathrm{C}$ & G & $\mathrm{C}$ & G & G & $\mathrm{T}$ & $\mathrm{C}$ \\
\hline 15670 & sabT2 & sab & $2 x$ & $\mathrm{C}$ & $\mathrm{C}$ & $\mathrm{T}$ & $\mathrm{T}$ & $\mathrm{A}$ & $\mathrm{C}$ & $\mathrm{C}$ & $\mathrm{T}$ & $\mathrm{C}$ & $\mathrm{C}$ & $\mathrm{C}$ & G & $\mathrm{C}$ & G & G & $\mathrm{T}$ & $\mathrm{C}$ \\
\hline 15673 & sabT2 & sab & $2 x$ & $\mathrm{C}$ & $\mathrm{C}$ & $\mathrm{T}$ & $\mathrm{T}$ & A & $\mathrm{C}$ & $\mathrm{C}$ & $\mathrm{T}$ & $\mathrm{C}$ & $\mathrm{C}$ & $\mathrm{C}$ & G & $\mathrm{C}$ & G & G & $\mathrm{T}$ & $\mathrm{C}$ \\
\hline 15675 & sabT2 & sab & $2 x$ & $\mathrm{C}$ & $\mathrm{C}$ & $\mathrm{T}$ & $\mathrm{T}$ & A & $\mathrm{C}$ & $\mathrm{C}$ & $\mathrm{T}$ & $\mathrm{C}$ & $\mathrm{C}$ & $\mathrm{C}$ & G & $\mathrm{C}$ & G & G & $\mathrm{T}$ & $\mathrm{C}$ \\
\hline B2 14723 & balkT2=sabT2 & bal & $4 x$ & $\mathrm{C}$ & $\mathrm{C}$ & $\mathrm{T}$ & $\mathrm{T}$ & A & $\mathrm{C}$ & $\mathrm{C}$ & $\mathrm{T}$ & $\mathrm{C}$ & $\mathrm{C}$ & $\mathrm{C}$ & G & $\mathrm{C}$ & G & G & $\mathrm{T}$ & $\mathrm{C}$ \\
\hline 15691 & balkT1=sabT1* & bal & $4 x$ & $\mathrm{C}$ & $\mathrm{C}$ & $\mathrm{T}$ & $\mathrm{T}$ & A & $\mathrm{C}$ & $\mathrm{C}$ & $\mathrm{T}$ & $\mathrm{C}$ & $\mathrm{C}$ & $\mathrm{C}$ & G & $\mathrm{C}$ & G & G & $\mathrm{T}$ & $\mathrm{C}$ \\
\hline B1 14934 & balkT1=sabT1 & bal & $4 x$ & $\mathrm{C}$ & $\mathrm{C}$ & $\mathrm{T}$ & $\mathrm{T}$ & A & $\mathrm{C}$ & $\mathrm{C}$ & $\mathrm{T}$ & $\mathrm{C}$ & $\mathrm{C}$ & $\mathrm{C}$ & G & $\mathrm{C}$ & G & $\mathrm{G}$ & $\mathrm{T}$ & $\mathrm{C}$ \\
\hline 15680 & balkT1=sabT1 & bal & $4 x$ & $\mathrm{C}$ & $\mathrm{C}$ & $\mathrm{T}$ & $\mathrm{T}$ & $\mathrm{A}$ & $\mathrm{C}$ & $\mathrm{C}$ & $\mathrm{T}$ & $\mathrm{C}$ & $\mathrm{C}$ & $\mathrm{C}$ & G & $\mathrm{C}$ & G & G & $\mathrm{T}$ & $\mathrm{C}$ \\
\hline 15684 & balkT1=sabT1 & bal & $4 x$ & $\mathrm{C}$ & $\mathrm{C}$ & $\mathrm{T}$ & $\mathrm{T}$ & A & $\mathrm{C}$ & $\mathrm{C}$ & $\mathrm{T}$ & $\mathrm{C}$ & $\mathrm{C}$ & $\mathrm{C}$ & G & $\mathrm{C}$ & G & G & $\mathrm{T}$ & $\mathrm{C}$ \\
\hline S1 7573 & sabT1 & $\mathrm{sab}$ & $2 x$ & $\mathrm{C}$ & $\mathrm{C}$ & $\mathrm{T}$ & $\mathrm{T}$ & A & $\mathrm{C}$ & $\mathrm{C}$ & $\mathrm{T}$ & $\mathrm{C}$ & $\mathrm{C}$ & $\mathrm{C}$ & G & $\mathrm{T}$ & G & G & $\mathrm{T}$ & $\mathrm{C}$ \\
\hline 15677 & sabT1 & sab & $2 x$ & $\mathrm{C}$ & $\mathrm{C}$ & $\mathrm{T}$ & $\mathrm{T}$ & A & $\mathrm{C}$ & $\mathrm{C}$ & $\mathrm{T}$ & $\mathrm{C}$ & $\mathrm{C}$ & $\mathrm{C}$ & G & $\mathrm{Y}$ & G & G & $\mathrm{T}$ & $\mathrm{C}$ \\
\hline 15682 & sabT1 & sab & $2 x$ & $\mathrm{C}$ & $\mathrm{C}$ & $\mathrm{T}$ & $\mathrm{T}$ & A & $\mathrm{C}$ & $\mathrm{C}$ & $\mathrm{T}$ & $\mathrm{C}$ & $\mathrm{C}$ & $\mathrm{C}$ & G & $\mathrm{Y}$ & G & G & $\mathrm{T}$ & $\mathrm{C}$ \\
\hline 15688 & sabT1 & sab & $2 x$ & $\mathrm{C}$ & $\mathrm{C}$ & $\mathrm{T}$ & $\mathrm{T}$ & A & $\mathrm{C}$ & $\mathrm{C}$ & $\mathrm{T}$ & $\mathrm{C}$ & $\mathrm{C}$ & $\mathrm{C}$ & G & $\mathrm{Y}$ & G & G & $\mathrm{T}$ & $\mathrm{C}$ \\
\hline 15683 & sabT1 & sab & $2 x$ & $\mathrm{C}$ & $\mathrm{C}$ & $\mathrm{T}$ & $\mathrm{T}$ & A & $\mathrm{C}$ & $\mathrm{C}$ & $\mathrm{T}$ & $\mathrm{C}$ & $\mathrm{C}$ & C & G & $\mathrm{T}$ & G & G & $\mathrm{T}$ & $\mathrm{C}$ \\
\hline S2 15628 & sabT1 & sab & $2 x$ & $\mathrm{C}$ & $\mathrm{C}$ & $\mathrm{T}$ & $\mathrm{T}$ & $\mathrm{A}$ & $\mathrm{C}$ & $\mathrm{C}$ & $\mathrm{T}$ & $\mathrm{C}$ & $\mathrm{C}$ & $\mathrm{C}$ & G & $\mathrm{C}$ & G & G & $\mathrm{T}$ & $\mathrm{C}$ \\
\hline 15667 & sabT1* & sab & $2 x$ & $\mathrm{C}$ & $\mathrm{C}$ & $\mathrm{T}$ & $\mathrm{T}$ & $\mathrm{A}$ & $\mathrm{C}$ & $\mathrm{C}$ & $\mathrm{T}$ & $\mathrm{C}$ & $\mathrm{C}$ & $\mathrm{C}$ & G & $\mathrm{T}$ & G & G & $\mathrm{T}$ & $\mathrm{C}$ \\
\hline 15685 & sabT1* & sab & $2 x$ & $\mathrm{C}$ & $\mathrm{C}$ & $\mathrm{T}$ & $\mathrm{T}$ & $\mathrm{A}$ & $\mathrm{C}$ & $\mathrm{C}$ & $\mathrm{T}$ & $\mathrm{C}$ & $\mathrm{C}$ & $\mathrm{C}$ & G & $\mathrm{C}$ & G & G & $\mathrm{T}$ & $\mathrm{C}$ \\
\hline 15662 & balkT1 $\mathrm{x}$ thu & bal & $4 x$ & $\mathrm{Y}$ & M & $\mathrm{Y}$ & $\mathrm{Y}$ & $\mathrm{R}$ & $\mathrm{Y}$ & M & $\mathrm{Y}$ & $\mathrm{T}$ & $\mathrm{T}$ & $\mathrm{C}$ & $\mathrm{K}$ & $\mathrm{T}$ & $\mathrm{R}$ & $\mathrm{R}$ & W & M \\
\hline 15665 & balkT1 $\mathrm{x}$ thu & bal & $4 x$ & $\mathrm{Y}$ & M & $\mathrm{Y}$ & $\mathrm{Y}$ & $\mathrm{R}$ & $\mathrm{Y}$ & M & $\mathrm{Y}$ & $\mathrm{T}$ & $\mathrm{T}$ & $\mathrm{C}$ & K & $\mathrm{T}$ & $\mathrm{R}$ & $\mathrm{R}$ & W & M \\
\hline 15669 & balkT1 $\mathrm{x}$ thu & bal & $4 x$ & $\mathrm{Y}$ & M & $\mathrm{Y}$ & $\mathrm{Y}$ & $\mathrm{R}$ & $\mathrm{Y}$ & M & $\mathrm{Y}$ & $\mathrm{T}$ & $\mathrm{T}$ & $\mathrm{C}$ & G & $\mathrm{T}$ & $\mathrm{R}$ & $\mathrm{R}$ & W & $\mathrm{M}$ \\
\hline 15672 & balkT1 $\mathrm{x}$ thu & bal & $4 x$ & $\mathrm{Y}$ & $\mathrm{M}$ & $\mathrm{Y}$ & $\mathrm{Y}$ & $\mathrm{R}$ & $\mathrm{Y}$ & M & $\mathrm{Y}$ & $\mathrm{T}$ & $\mathrm{T}$ & $\mathrm{C}$ & G & $\mathrm{T}$ & $\mathrm{R}$ & $\mathrm{R}$ & W & $\mathrm{M}$ \\
\hline 15676 & balkT1 $\mathrm{x}$ thu & bal & $4 x$ & $\mathrm{Y}$ & $\mathrm{M}$ & $\mathrm{Y}$ & $\mathrm{Y}$ & $\mathrm{R}$ & $\mathrm{Y}$ & $\mathrm{M}$ & $\mathrm{Y}$ & $\mathrm{T}$ & $\mathrm{T}$ & $\mathrm{C}$ & $\mathrm{N}$ & $\mathrm{T}$ & $\mathrm{R}$ & $\mathrm{R}$ & W & $\mathrm{M}$ \\
\hline 15664 & balkT1 $\mathrm{x}$ thu & bal & $4 x$ & $\mathrm{Y}$ & M & $\mathrm{Y}$ & $\mathrm{Y}$ & $\mathrm{R}$ & $\mathrm{Y}$ & $\mathrm{M}$ & $\mathrm{Y}$ & $\mathrm{T}$ & $\mathrm{T}$ & $\mathrm{M}$ & $\mathrm{T}$ & $\mathrm{T}$ & $\mathrm{R}$ & $\mathrm{R}$ & W & $\mathrm{M}$ \\
\hline 15666 & balkT1 $\mathrm{x}$ thu & bal & $4 x$ & $\mathrm{~T}$ & $\mathrm{M}$ & $\mathrm{Y}$ & $\mathrm{Y}$ & $\mathrm{R}$ & $\mathrm{Y}$ & M & $\mathrm{Y}$ & $\mathrm{T}$ & $\mathrm{T}$ & $\mathrm{C}$ & $\mathrm{T}$ & $\mathrm{T}$ & $\mathrm{R}$ & $\mathrm{R}$ & W & $\mathrm{M}$ \\
\hline 15687 & balkT1 $\mathrm{x}$ thu & bal & $4 x$ & $\mathrm{Y}$ & $\mathrm{M}$ & $\mathrm{Y}$ & $\mathrm{Y}$ & $\mathrm{R}$ & $\mathrm{Y}$ & $\mathrm{C}$ & $\mathrm{Y}$ & $\mathrm{T}$ & $\mathrm{T}$ & $\mathrm{C}$ & $\mathrm{T}$ & $\mathrm{T}$ & $\mathrm{R}$ & $\mathrm{R}$ & W & M \\
\hline 15689 & balkT1 $\mathrm{x}$ thu & bal & $4 x$ & $\mathrm{Y}$ & M & $\mathrm{Y}$ & $\mathrm{Y}$ & $\mathrm{R}$ & $\mathrm{Y}$ & $\mathrm{M}$ & $\mathrm{Y}$ & $\mathrm{T}$ & $\mathrm{T}$ & $\mathrm{C}$ & $\mathrm{N}$ & $\mathrm{T}$ & $\mathrm{R}$ & $\mathrm{R}$ & $\mathrm{W}$ & A \\
\hline 15679 & balkT1 $\mathrm{x}$ thu & bal & $4 x$ & $\mathrm{Y}$ & $\mathrm{M}$ & $\mathrm{C}$ & $\mathrm{Y}$ & $\mathrm{R}$ & $\mathrm{T}$ & $\mathrm{C}$ & $\mathrm{Y}$ & $\mathrm{T}$ & $\mathrm{T}$ & $\mathrm{C}$ & $\mathrm{N}$ & $\mathrm{T}$ & $\mathrm{R}$ & $\mathrm{R}$ & W & $\mathrm{M}$ \\
\hline 15668 & balkT1 $\mathrm{x}$ thu & bal & $4 x$ & $\mathrm{Y}$ & M & $\mathrm{Y}$ & $\mathrm{Y}$ & $\mathrm{R}$ & $\mathrm{Y}$ & $\mathrm{C}$ & $\mathrm{Y}$ & $\mathrm{Y}$ & $\mathrm{Y}$ & $\mathrm{C}$ & G & $\mathrm{T}$ & $\mathrm{R}$ & $\mathrm{R}$ & W & M \\
\hline 15663 & balkT1 $\mathrm{x}$ thu & bal & $4 x$ & $\mathrm{Y}$ & $\mathrm{M}$ & $\mathrm{Y}$ & $\mathrm{Y}$ & $\mathrm{R}$ & $\mathrm{Y}$ & $\mathrm{C}$ & $\mathrm{Y}$ & $\mathrm{T}$ & $\mathrm{T}$ & $\mathrm{C}$ & $\mathrm{T}$ & $\mathrm{C}$ & $\mathrm{R}$ & $\mathrm{R}$ & A & $\mathrm{M}$ \\
\hline 15681 & balkT1 $\mathrm{x}$ thu & bal & $4 x$ & $\mathrm{Y}$ & M & $\mathrm{Y}$ & $\mathrm{Y}$ & $\mathrm{R}$ & $\mathrm{Y}$ & $\mathrm{C}$ & $\mathrm{Y}$ & $\mathrm{C}$ & $\mathrm{Y}$ & $\mathrm{C}$ & $\mathrm{N}$ & $\mathrm{T}$ & G & $\mathrm{R}$ & W & $\mathrm{M}$ \\
\hline 15686 & balkT1 $\mathrm{x}$ thu & bal & $4 x$ & $\mathrm{Y}$ & $\mathrm{M}$ & $\mathrm{Y}$ & $\mathrm{Y}$ & $\mathrm{R}$ & $\mathrm{Y}$ & $\mathrm{C}$ & $\mathrm{Y}$ & $\mathrm{C}$ & $\mathrm{T}$ & $\mathrm{C}$ & $\mathrm{N}$ & $\mathrm{T}$ & G & $\mathrm{R}$ & W & $\mathrm{M}$ \\
\hline 15690 & balkT1 $\mathrm{x}$ thu & bal & $4 x$ & $\mathrm{C}$ & M & $\mathrm{Y}$ & $\mathrm{Y}$ & $\mathrm{R}$ & $\mathrm{Y}$ & $\mathrm{C}$ & $\mathrm{Y}$ & $\mathrm{C}$ & $\mathrm{C}$ & $\mathrm{C}$ & G & $\mathrm{T}$ & G & $\mathrm{R}$ & $\mathrm{W}$ & M \\
\hline 15671 & BC thu & bal & $4 x$ & $\mathrm{~T}$ & A & C & C & $\mathrm{R}$ & $\mathrm{T}$ & $\mathrm{M}$ & C & $\mathrm{T}$ & $\mathrm{T}$ & C & K & $\mathrm{T}$ & A & A & A & A \\
\hline 15674 & $\mathrm{BC}$ thu & bal & $4 x$ & $\mathrm{~T}$ & A & $\mathrm{C}$ & C & $\mathrm{R}$ & $\mathrm{T}$ & M & $\mathrm{C}$ & $\mathrm{T}$ & $\mathrm{T}$ & $\mathrm{M}$ & $\mathrm{K}$ & $\mathrm{T}$ & A & A & A & A \\
\hline 15678 & $\mathrm{BC}$ thu & bal & $4 x$ & $\mathrm{~T}$ & A & $\mathrm{C}$ & $\mathrm{C}$ & A & $\mathrm{T}$ & A & $\mathrm{C}$ & $\mathrm{T}$ & $\mathrm{T}$ & A & G & $\mathrm{T}$ & A & A & A & A \\
\hline T1 15616 & thu & thu & $4 x$ & $\mathrm{~T}$ & A & $\mathrm{C}$ & $\mathrm{C}$ & G & $\mathrm{T}$ & $\mathrm{C}$ & $\mathrm{C}$ & $\mathrm{T}$ & $\mathrm{T}$ & $\mathrm{C}$ & $\mathrm{T}$ & $\mathrm{T}$ & A & A & A & A \\
\hline T2 15617 & thu & thu & $4 x$ & $\mathrm{~T}$ & A & C & C & G & $\mathrm{T}$ & $\mathrm{C}$ & C & $\mathrm{T}$ & $\mathrm{T}$ & C & $\mathrm{T}$ & $\mathrm{T}$ & A & A & A & A \\
\hline
\end{tabular}

types of diploid J. sabina. It should be noted that nrDNA sequences in J. sabina are polymorphic, designated as Type 1 and Type $2[15,17,29,38]$, comprising 8 SNPs. The most recent survey of Type 1 (T1) and Type 2 (T2) ITS occurrences [17] examined $66 \mathrm{~J}$. sabina samples from throughout the known range of J. sabina var. sabina and J. sabina var. balkanensis and found to be $27.3 \%$ Type 1, 4.5\% Type 2 and $68.2 \%$ intermediate (T1 $\mathrm{x}$ T2 hybrids and backcrosses). Thus, it was important to determine the presence of $\mathrm{T} 1$ and $\mathrm{T} 2$ in the Spain putative hybrid populations, as this could skew the analysis of hybridization between J. thurifera and J. sabina var. sabina. In addition, two sets of heteroploid hybrids $(2 n=3 x)$ have been identified, both of them involving J. thurifera $(2 n=4 x)$ as one parent and the second parent being $J$. sabina Type 1 or Type $2(2 n=2 x)$.

Interestingly, among our samples, we did not find $J$. sabina var. sabina Type 2 , but by finding the categories of hybrids cited above, it is very probable that Type 2 plants are present in a nearby population. It should be noted that, at present, nrDNA Type 1 and 2 , are not 


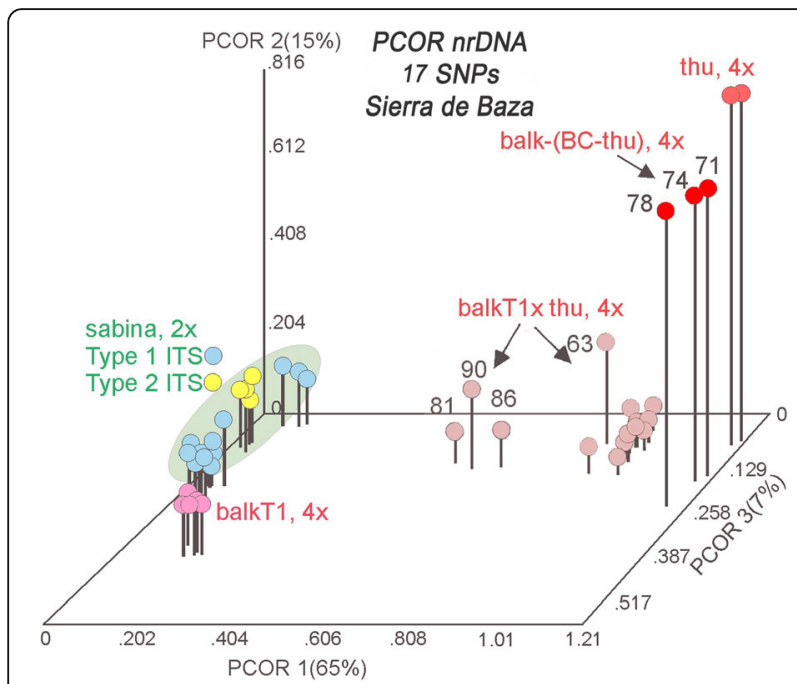

Fig. 4 PCOR of Juniperus studied taxa from Sierra de Baza using 17 SNPs of nrDNA data. The PCOR ordination includes $30 \mathrm{~J}$. sabina var. sabina and $J$. sabina var. balkanensis plus two reference $J$. thurifera samples. Note the clear separation of $J$. sabina var. sabina and $J$. sabina var. balkanensis from $J$. thurifera and the hybrids $J$. sabina var. balkanensis $\times J$. thurifera

associated with any morphological trait nor terpenoid(s) in the leaf essential oils [39], and thus, could not be selected during our sampling. The discovery that the two types of J. sabina hybridize and both could hybridize with $J$. thurifera would increase the genetic diversity of the offspring individuals and they may exhibit a reproductive isolation from the parental species leading to the speciation [40, 41]. In the E Iberian Range populations, we did not found backcrosses from the triploid hybrid with any of the parental species, which suggest the presence of a breeding barrier between the triploids and the parental species. Nevertheless, we found two triploid hybrids (15646 and 15774) that are probably the offspring generated from a cross between two triploid hybrids (thu $x$ sabT1) $x$ (thu $x$ sabT2) based on their SNPs. This means that a fertilization was probably between a haploid gamete $(n=1 x)$ with a diploid gamete $(n=2 x)$ produced by the triploid parental hybrids. Hybridization between two triploids giving rise to a triploid hybrid is quite rare due to the high sterility and meiotic problems of triploid hybrids, as described in many studies [26]. However, it has been shown that triploids are not completely sterile and could produce some viable gametes of three ploidy levels $(n=1 x ; n=2 x$ and $n=3 x)[26,42$, 43]. In Juniperus, the production of reduced, partially reduced and unreduced male gametes has been suggested for the triploid hybrids found in the Alps based on the significant variation of pollen sizes [18]. Interestingly, those hybrids, found very recently in the French Alps, were also between J. thurifera and J. sabina var. sabina present in a sympatric occurrence [18]. The hybridization events found between $J$. thurifera and $J$. sabina in the French Alps (France) and in the E Iberian Range (Spain), suggest that the reproductive barriers between those two species are ineffective despite the difference of ploidy levels.

All triploid hybrids found in this study shared the same chloroplast marker trnS-G which is the J. thurifera cp Type. Preliminary analysis of four cp DNA markers (petN-psbM, trnS-G, trnL-F and trnD-T) revealed that all four distinguished J. sabina from J. thurifera $[5,15$, 17], but cp marker trnS-G yielded the largest number of informative SNPs. Chloroplasts appear to be inherited via pollen in Juniperus, because the chloroplasts of Cupressaceae species examined to date have been shown mainly to be paternally inherited [44]. Thus, all 22 hybrids were derived from unidirectional crosses involving male (pollen) J. thurifera trees. The unidirectional crossing seems to imply $J$. thurifera has evolved a reproductive barrier against $J$. sabina pollen, but not vice-versa. Unidirectional interspecific hybridization has been reported in several genera in angiosperms [45-47] and in gymnosperms, especially in Pinus L. [48] and in Juniperus [49]. Lepais et al. [50], suggested that unidirectional gene flow in sympatry could be affected by the relative abundance of species where introgression will be from the more frequent species to the less frequent one. However, it seems that this hypothesis is not valid in the two cases of hybrids found in the French Alps and Spain, due to the approximately similar abundance of both $J$. sabina var. sabina and $J$. thurifera in those locations. However, the unidirectional hybridization could be due to the difference in timing of reproduction between those two species. Juniperus thurifera sheds pollen in the winter but J. sabina var. sabina sheds pollen in the late winter till spring [6]. Usually, flowering and shedding pollen co-occur to insure the good reproduction in dioecious species which is the case of both J. sabina var. sabina and $J$. thurifera. See section below for extensive discussion about overlapping pollen shedding times.

Interestingly, in contrast to angiosperms where crosses seem to be more successful when the maternal parent has a higher ploidy level [26], in the studied Juniperus, the paternal parent was shown to be tetraploid and the maternal parent as diploid in all triploid hybrids. The main factor implicated in the inter-ploidy hybridization in angiosperms is the endosperm maternal/ paternal ratio that was destructive when the paternal parent had a higher ploidy level than the maternal parent leading to an aborted seed [26]. The fact that there is no endosperm in Juniperus this could be one of the reasons of the interspecific hybridization success regardless of the maternal and paternal parents' ploidy levels. However, this hypothesis must be taken with high caution because 
no research has been done to date to study the presence of genetic barriers that prohibit the hybridization between a female $J$. thurifera $(2 n=4 x)$ and a male J. sabina $(2 n=2 x)$. Clearly, further studies are needed in this field.

\section{Allopatric introgression in the Sierra de Baza population}

Allopatric hybridization and introgression in Juniperus have been frequently reported $[9-12,15,51-54]$. So, it is not surprising to find the DNA data clearly supports introgression by pollen from allopatric $J$. thurifera into $J$. sabina var. balkanensis, Type 1 (Figs. 3, 4) in the Sierra de Baza population. In the present population, based on the ploidy and the results of trnS-G and ITS, those tetraploid hybrids may arise from a fertilization between normally reduced diploid gamete $(n=2 x)$ from the tetraploid taxa J. thurifera and J. sabina var. balkanensis. We couldn't distinguish between male and female parental taxa because J. thurifera and J. sabina var. balkanensis have the same chloroplast sequences $[15,29,38]$. We expected to find triploid hybrids between $J$. sabina var. sabina $(2 x)$ and J. sabina var. balkanensis $(4 x)$ at Sierra de Baza in an analogous fashion as we found in the $E$ Iberian Range populations where there were triploid hybrids between J. sabina var. sabina and J. thurifera. In E Iberian Range populations, J. thurifera and J. sabina var. sabina grew intermingled on hillsides, and triploids were found scatter among them. At the Sierra de Baza population, J. sabina var. sabina and J. sabina var. balkanensis grew intermingled. Yet no triploids were found. There may have developed some isolating mechanism(s) to prevent hybridization between these varieties which could be a strategy to speciation in the case of J. sabina. In fact, reproductive isolation was shown to play a central role leading to speciation with pre or post-zygotic barriers [26, 55-57].

In contrast to the E Iberian Range populations, where it appears that most hybrid individuals were holding highly similar ITS sequences suggesting being first generation, at Sierra de Baza, most tetraploid hybrids showed genetic diversity suggesting to be more as F2 or higher generation level backcrossed to J. thurifera as obviously observed in 15671-15674 and 15678 hybrids. This could be due to the high gametes abortion in triploid hybrids due to unbalanced meiotic chromosome segregation and numerous meiotic abnormalities we cite the precocious cytokinesis found in allotriploid poplar [43]. Meiosis might be more stable or reaching faster a stable condition in allo-tetraploid than in allotriploid. This would be one of the reasons to find more diversity in allo-tetraploid hybrids produced in "one step" between two tetraploid parental species than the allo-triploid hybrids that could have more serious problems in meiosis. Interestingly, in this population we found backcrosses of the hybrids with $J$. thurifera and none with $J$. sabina suggesting an unidirectional gene flow as observed in E Iberian Range populations. Unfortunately, we don't have data for pollen and flowering periods of $J$. sabina var. balkanensis and the hybrids found, to check possible pre-zygotic reproductive barriers. However, further work will be dedicated to discover the reproductive barriers between this group of taxa.

\section{Overlapping pollen shedding/ receptive female cones seasons}

Literature reports of pollen shedding times for J. thurifera vary from: winter [6]; flower(s) by January [58]; flower(s) at the end of winter period [59]; late winterearly spring [60], between January and May [61, 62].

Pollen shedding time for $J$. sabina has been reported as late winter-spring [6], April ([61, 62], mid-MarchApril (French Alps, pers. comm. Thierry Robert), AprilMay (Bulgaria, pers. comm., Alex Tashev). A summary for $J$. thurifera depicts (Table 4) the prime or most likely pollen shedding times are in red (January, February). Less likely pollen shedding times are in orange and rarely occurring times in yellow (Table 4) and likewise for J. sabina. Note that the overlapping times of major pollen release ( $J$. thurifera) and major receptive cones of J. sabina are February-March (Table 4). Thus, clearly these taxa have an overlapping season for gene exchange (as demonstrated by the production of hybrids in the $\mathrm{E}$ Iberian Range populations).

Even if pollen shedding times scarcely overlap, given many years of seasons and that pollen shedding times vary from year to year, occasionally, pollen shedding will likely overlap. An exceptional study on variation in pollen shedding times for J. virginiana airborne pollen over a 10-year period [64] found (Fig. 5) that the start of pollen shedding varied from 2 February (1990) to 13 February (1992). The termination of pollen shedding was very variable from March 11 to April 10 (Fig. 5). Notice that 1988 was an unusual year in having a very short pollen shedding time (February 21-March 11, 19 days of airborne J. virginiana pollen). And, 1993 had an exceptionally long season from February 3-April 10, 67 days of airborne pollen. Pollen shedding (release) in late winter and spring is dependent on two temperature factors [64]: chilling requirement to end dormancy [65] and accumulation of heat units above a threshold temperature $[65,66]$. Pollen is released from junipers on warm, dry days and often one will see a sudden yellow, pollen cloud rising above a juniper tree as the morning sun warms and dries the air and pollen cones.

Pertinent to this discussion is the fact that a significant amount of Juniperus pollen can travel very long distances by wind. For example, major concentrations of $J$. ashei J. Buchholz pollen (shed in December-January) are 
Table 4 Data for wind direction, frequency (freq.) (\%), and velocity ( $\mathrm{kph}=\mathrm{km} / \mathrm{h}$ ) along with major (red) and minor (yellow) pollen shedding times for J. sabina and J. thurifera. Wind data from city of Baza, Spain [63]. Times of receptive cones are highly correlated with pollen shedding (time) in Juniperus [60]. na = not applicable. North-northeast (NNE), east-northeast (ENE), east-southeast (ESE), south-southeast (SSE), south-southwest (SSW), west-southwest (WSW), west-northwest (WNW) and north-northwest (NNW).

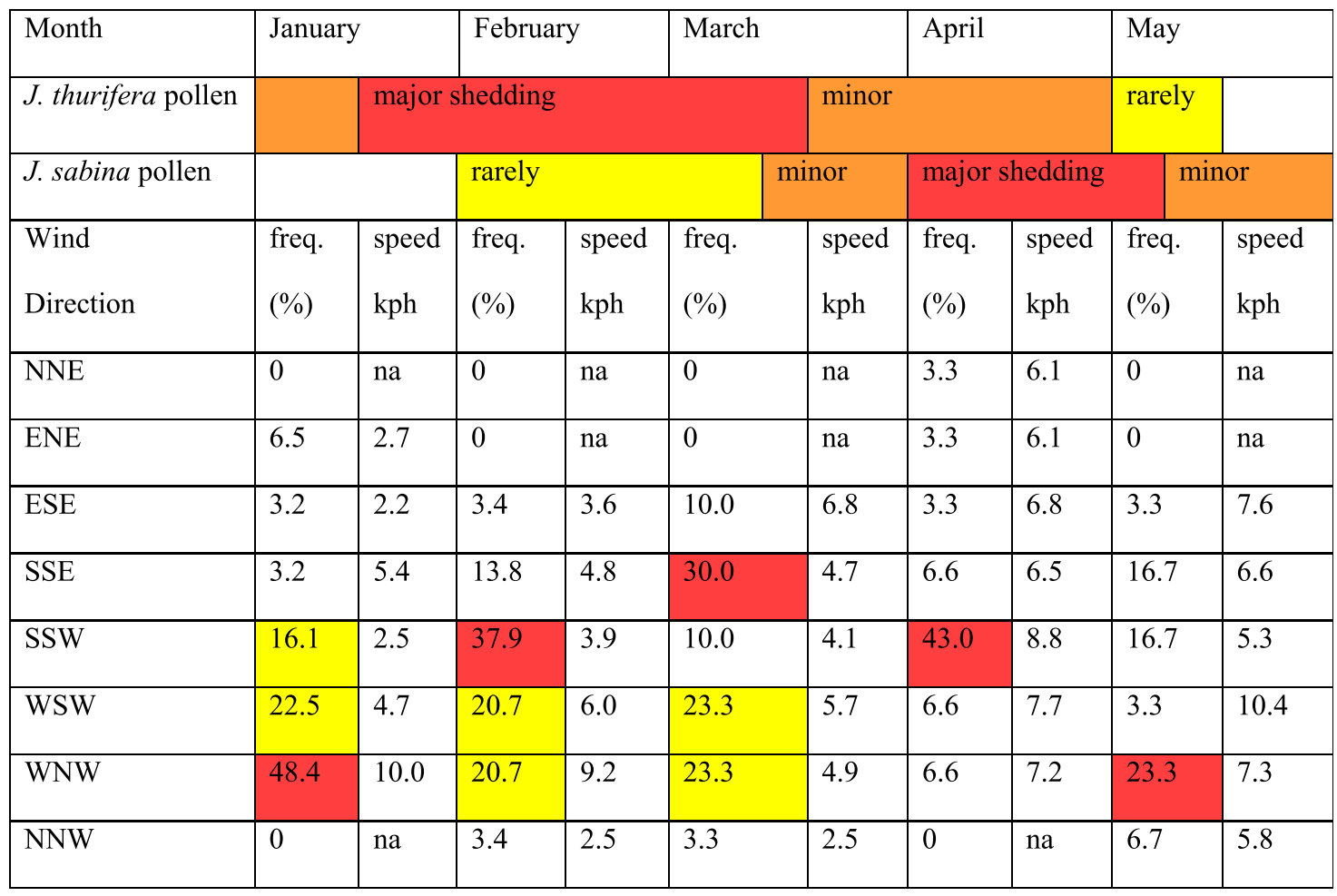

blown to Tulsa, Oklahoma from the nearest major pollen source, $320 \mathrm{~km}$ south, in southern Oklahoma and Texas.

Levetin [64] notice (Table 5) that in 1993-94 and 199596, maximum concentrations of $J$. ashei pollen were greater than for the local J. virginiana. This shows that even after traveling more than $320 \mathrm{~km}$, the concentration of distant pollen can be on the same level as local pollen.
Recently, it has been proven by DNA analysis of individual pollen grains, that $J$. ashei from Texas traveled to and was collected in Ontario, Canada, approximately $2400 \mathrm{~km}$ [67].

Several other studies in conifers have reported long distance transport (LDT) of pollen from a few $\mathrm{km}$ to several hundred $\mathrm{km}$ [68-74]. Importantly, several studies have reported that LDT pollen has maintained its viability [75-77]. Pollen from Juniperus communis L., in the

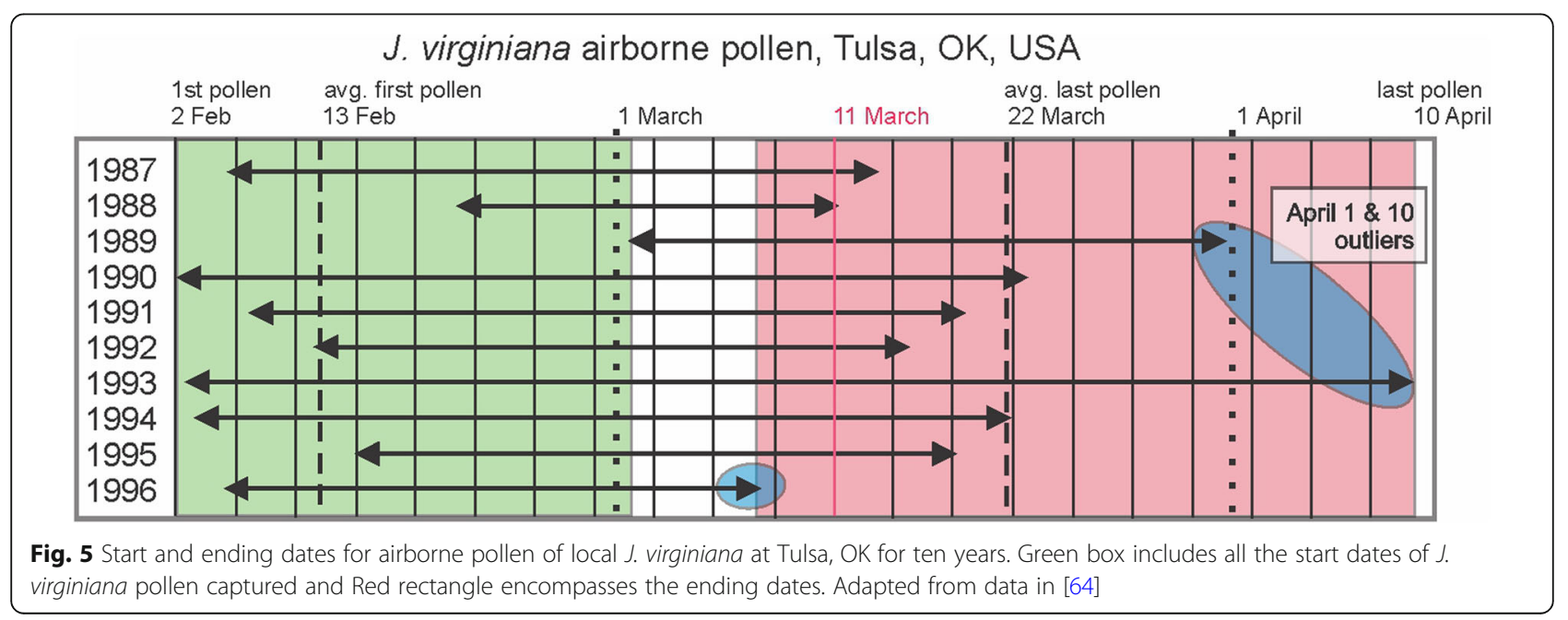


Table 5 Comparison peak concentrations of airborne J. ashei pollen (December-January) to J. virginiana pollen (February-March) captured at Tulsa, OK. * = concentration of invasive pollen higher than local pollen

\begin{tabular}{|c|c|c|c|}
\hline \multirow[b]{2}{*}{$\begin{array}{l}\text { year } \\
\text { (season) }\end{array}$} & \multicolumn{2}{|l|}{ Peak concentration, pollen grains $/ \mathrm{m}^{3}$} & \multirow[b]{2}{*}{$\begin{array}{l}\text { foreign (J. ashei) vs. } \\
\text { vs. local (J. virginiana) pollen }\end{array}$} \\
\hline & J. ashei, from southern Oklahoma, Texas & J. virginiana from local Tulsa area & \\
\hline $1987-88$ & 175 & 655 & $0.27: 1$ \\
\hline 1988-89 & 546 & 1057 & $0.51: 1$ \\
\hline 1989-90 & 257 & 1115 & $0.23: 1$ \\
\hline 1990-91 & 333 & 4442 & $0.07: 1$ \\
\hline 1991-92 & 158 & 1156 & $0.14: 1$ \\
\hline 1992-93 & 802 & 1248 & $0.64: 1$ \\
\hline 1993-94 & 2027 & 1311 & $1.55: 1^{*}$ \\
\hline 1994-95 & 947 & 1485 & $0.64: 1$ \\
\hline 1995-96 & 2411 & 2027 & $1.19: 1^{*}$ \\
\hline
\end{tabular}

western Alps, was stored at ambient conditions and found to be $40-90 \%$ viable in fresh pollen, $20-40 \%$ viable after 2 weeks and $0-10 \%$ viable after 2 months storage [78].

At present, very few field studies in conifers have shown that LDT viable pollen is effective (that is, able to fertilize receptive strobili). However, in a small isolated population of Pinus sylvestris L., in Spain, effective pollen was discovered $100 \mathrm{~km}$ from the source at a rate of 4.4\% [79, 80]. Molecular markers (4 chloroplast and nuclear microsatellites (SSR) were used to perform paternity tests on 813 seeds. Although 778 seeds had fathers of local origin, $4.3 \%$ (35) seed fathers were from immigrant LDT pollen [80].

Finally, it should be mentioned that in a preliminary study on LDT pollen viability, Levetin (per. Comm.) has found viable Juniperus ( $J$. ashei) LDT airborne pollen in Tulsa after having traveled at least $320 \mathrm{~km}$ from southern Oklahoma, Texas.

\section{Potential source of J. thurifera nearby the Sierra de Baza J. sabina var. balkanensis population}

Examination of distributions of $J$. thurifera and J. sabina in the area (Fig. 6) reveals several $J$. thurifera populations Northeast of Sierra de Baza and a significant population of J. thurifera in the Alamedilla area, west-northwest (WNW) of Sierra de Baza. Although FAME database contained only 57 records from the Alamedilla area, there are likely many more trees around Alamedilla than 57. In the cases of Guadix (1) and Hoya de Baza (1), these sites each have only a single, isolated tree (personal observation, Carlos Salazar-Mendias (CSM)). The nearest large population of $J$. thurifera is Alamedilla that is approximately $26 \mathrm{~km}$ from J. sabina var. balkanensis, Sierra de Baza (Fig. 6).

Wind direction and velocity are essential factors for LDT of pollen grains that are dispersed by wind which is the case in Juniperus. Analyses of wind directions and velocities for January, February, March, April and May show (Table 4) the major directions are from: WNW, 48.4\%, $10.0 \mathrm{kph}$ (January); south-southwest (SSW), 37.9\%, 3.9 kph (February); south-southeast (SSE), 30.0\%, $4.7 \mathrm{kph}$ (March), SSW, 43\%, $8.8 \mathrm{kph}$ (April) and WNW, $23.3 \%, 7.3 \mathrm{kph}$ (May). Overall the wind velocities were not very large, ranging from 2.2 to $10.0 \mathrm{kph}$.

Graphical wind directional analyses reveal the prevailing winds for January and February are similar being from the west, northwest and southwest (Fig. 7). A second pattern emerges in March, but considerable winds blow from WNW (23.3\%) and west-southwest (WSW) (23.3\%), but with $30 \%$ of the winds from SSE (Fig. 7). In April, the prevailing wind pattern is clearly different as wind blows (43\%) from the SSW.

The major times for pollen release from $J$. thurifera are January-February-March (note Table 4) and this coincides with the prevailing winds from Alamedilla to $\mathrm{Si}$ erra de Baza. Given the overlap pollen shedding (and receptive female cones), it would seem that all the factors align to support the DNA data of allopatric introgression via $J$. thurifera pollen upon receptive female strobili of J. sabina var. balkanensis, Type 1 (Fig. 4) to produce backcrossed progeny towards $J$. thurifera.

\section{Potential factors that interfere in the hybridization and polyploidy of the Spanish populations}

Polyploidy and hybridization have been shown to be influenced by environmental and geographical factors. As an example, plant species migrate to new niches with more favorable environmental factors, thus providing a new sympatric occurrence with a sister species, which could lead to new opportunities for interspecific hybridization $[82,83]$. In addition, extreme temperatures have been proven to induce unreduced gametes formation [84, 85],which is a major mechanism leading to 


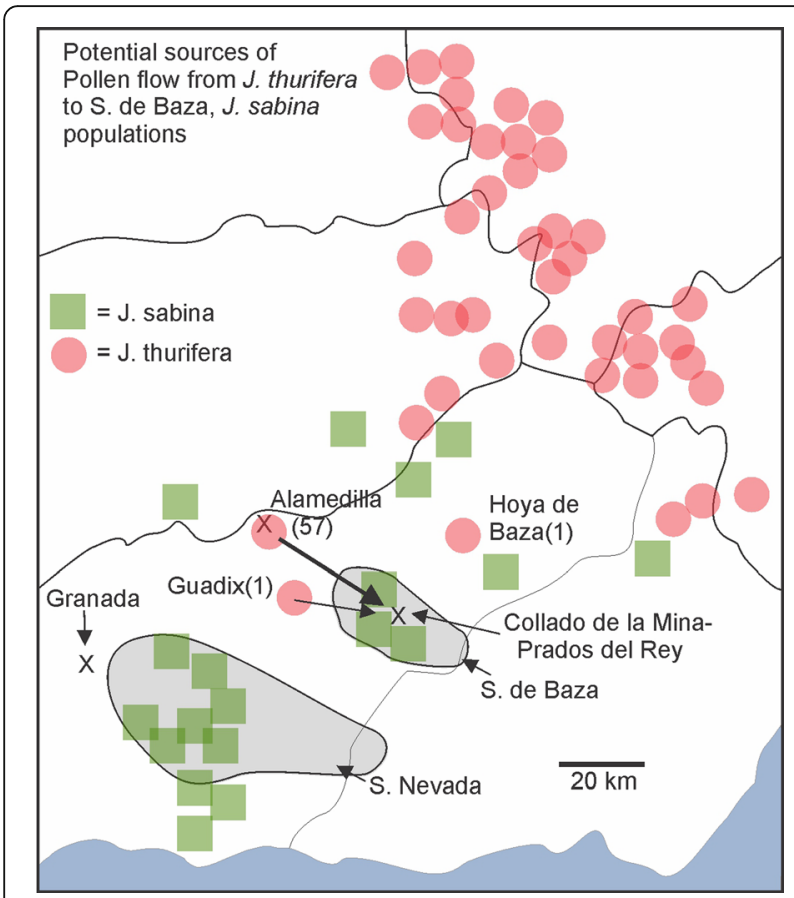

Fig. 6 Distribution of J. thurifera and J. sabina in the region around Sierra de Baza (S. de Baza). Data from Anthos Spanish Plants Information System (http://www.anthos.es/index.php?lang=en) and FAME database [81]. Numbers in parenthesis are the number of records in FAME database for that location (ex. Alamedilla (57) denotes 57 records at that location)

polyploidy $[1,26]$. In the present case, the polyploid taxa (J. thurifera and J. sabina var. balkanensis) are tetraploid in all populations studied to date [29, 86]. In the Spanish populations studied, interspecific hybridization was shown to be the driver for polyploid formation (triploid hybrids in the E Iberian Range and tetraploid hybrids in Sierra de Baza). Sierra de Baza area is subjected to LDT of $J$. thurifera pollen blown into this population appears to have led to the formation of tetraploid hybrids with $J$. sabina var. balkanensis. The E Iberian Range, where the populations of hybrids between J. thurifera and J. sabina occur in this study, is characterized in its central region by extreme variation in its continental climate, with wide thermal gradients between day and night $\left(17\right.$ to $20^{\circ} \mathrm{C}$ on average) and frequent thermal inversion phenomena [87]. The lowest temperatures ever recorded in inhabited areas in Spain have occurred in this geographical environment, with episodes of very cold weather that recur over periods of 6-8 years on average, in which the minimum temperatures can drop to $-20^{\circ} \mathrm{C}$, with a record low of $-30^{\circ} \mathrm{C}$ in December 1963 [88]. These facts may have influenced the facilitation of hybridization processes. Normally, the optimum altitude of J. sabina, in the E Iberian Range is above $1600 \mathrm{~m}$. However, the phenomena of thermal inversion (accumulation of cold air at the bottom of valleys in calm periods) could have favored the migration of J. sabina to lower altitudes (1300-1400 m) and, thus, may led to sympatric populations with $J$. thurifera in several wide-spread areas. This sympatry has facilitated interspecific hybridization between J. sabina and J. thurifera. In addition, environmental factors may interfere in the phenology of the species as reported in several studies [89, 90], and thus, led to a longer time period of reproductive overlapping. Further studies are needed on the biogeography and phenology related to environmental factors in the Spanish populations to investigate these hypotheses.

\section{Conclusion}

This study reports the evidence of gene flow between diploid and tetraploid juniper taxa in sympatric occurrence in Spain. The populations of E Iberian Range presented triploid hybrids between the diploid J. sabina var. sabina and the tetraploid J. thurifera. Those hybrids were most probably of first generation. The population of Sierra de Baza showed just tetraploid hybrids, suggested to be between the two tetraploid taxa J. sabina var. balkanensis and J. thurifera based on ITS sequences. In this population, hybrids showed to be genetically diverse and suggested to be of F2 or higher generation level and making backcrosses with the parental species $J$. thurifera.

The studied taxa showed diversity in polyploidy pathways between the two populations; via "triploid bridge" as suggested in E Iberian Range populations and "One step polyploidy" as suggested for Sierra de Baza hybrids. However, future work on population genetics especially for Sierra de Baza population is needed using hybridization based target enrichment and NGS sequencing to study the largest number of low copy genes and to have more clear results on the hybrids backcrosses and gene flow. In addition, this further work will help in the detection of the positive selection genes and their relative functions which could be related in the adaptation and regulation of polyploid junipers.

Moreover, we showed evidence of unidirectional gene flow in both studied populations. In the E Iberian Range populations, the unidirectional gene flow showed from $J$. thurifera to J. sabina suggests pre-zygotic barriers related to different phenology favoring always (till now) the hybridization from J. thurifera to J. sabina. In Sierra de Baza population, the unidirectional gene flow was shown between the hybrids and one of the parental species J. thurifera suggesting reproductive barriers developed in the hybrids towards the parental species $J$. sabina. Yet, further work is needed to discover the mechanisms of reproductive barriers involved in the studied taxa shaping their gene flow and evolution. 

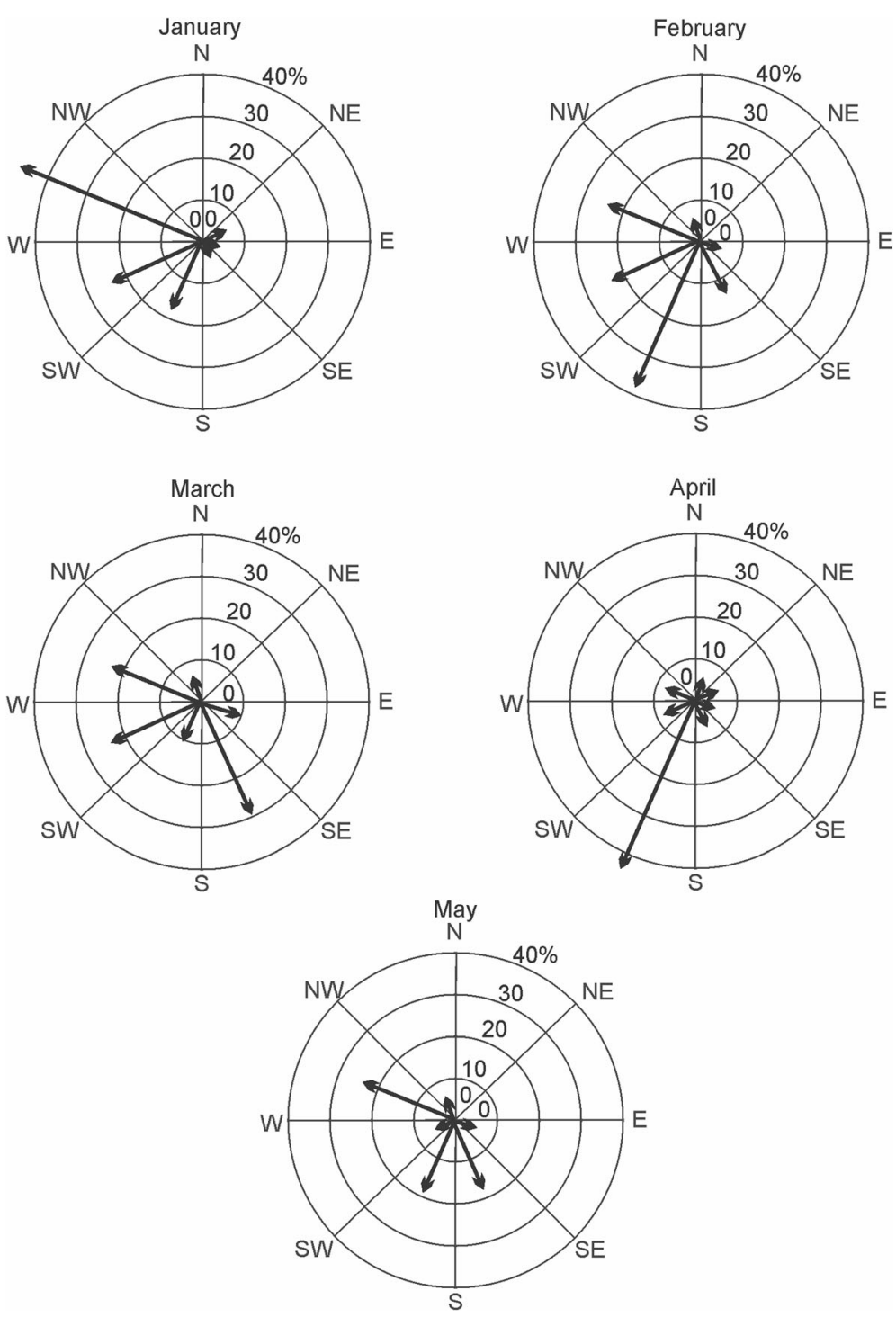

Fig. 7 Frequencies of wind directions, Baza, Spain for January, February, March, and April. The most dominant directions were from WNW, 48.4\% (January) and SSW, 43\% (April). Source: (Wind data from city of Baza, Spain [63])

\section{Methods}

\section{Plant collections}

Leaf samples were made from natural populations (see additional file 2). One gram (fresh weight) of the foliage was placed in $20 \mathrm{~g}$ of activated silica gel and transported to the lab, thence stored at $-20^{\circ} \mathrm{C}$ until $70 \mathrm{mg}$ of the silica gel dried leaves was used for ploidy determination by flow cytometry. In addition, genomic DNA (10-12 mg of the silica gel dried leaves) was extracted for sequencing.

\section{DNA analyses}

DNA was extracted from juniper leaves by use of a Qiagen mini-plant kit (Qiagen, Valencia, CA) as per manufacturer's instructions. Amplifications were performed in
$30 \mu \mathrm{l}$ reactions using $6 \mathrm{ng}$ of genomic DNA, 1.5 units Epi-Centre Fail-Safe Taq polymerase, $15 \mu \mathrm{l} 2 \mathrm{x}$ buffer E (trnS-trnG) or K (nrDNA) (final concentration: $50 \mathrm{mM}$ $\mathrm{KCl}, 50 \mathrm{mM}$ Tris- $\mathrm{HCl}$ (pH 8.3), $200 \mu \mathrm{M}$ each dNTP, plus Epi-Centre proprietary enhancers with $1.5-3.5 \mathrm{mM}$ $\mathrm{MgCl}_{2}$ according to the buffer used) and $1.8 \mu \mathrm{M}$ each primer. The primers for ITS (nrDNA) and cp trnS-trnG regions have been previously reported [91, 92]. The PCR reaction was subjected to purification by agarose gel electrophoresis. In each case, the band was excised and purified using a Qiagen QIAquick gel extraction kit (Qiagen, Valencia, CA). The gel purified DNA band with the appropriate sequencing primer was sent to McLab Inc. (San Francisco) for sequencing. 2.31 (Technelysium 
Pty Ltd.). Principle Coordinates (PCOR) and Minimum spanning networks software follows the formulations Veldman [20] Ordination and Adams [93].

\section{Genome size analyses Sample preparation}

Nuclear DNA amounts were assessed by flow cytometry using silica gel dried leaves of Juniperus samples and fresh leaves of the internal standard (IS) Hordeum vulgare L., cv. 'Sultan' ( $2 \mathrm{C}$ value $=9.81 \mathrm{pg}$ ) [94]. Around 30 $\mathrm{mg}$ of the IS and juniper leaves were simultaneously chopped in $600 \mathrm{ul}$ of cold Gif nuclear isolation bufferGNB [95]. The nuclei suspension was filtered using a nylon mesh $(50 \mu \mathrm{m})$ and stained with $100 \mu \mathrm{g} / \mathrm{ml}$ propidium iodide (PI).

\section{Flow cytometry analyses}

DNA contents $(\sim 3000$ stained nuclei) were determined using CytoFLEX $\mathrm{S}$ flow cytometer (Beckman CoulterLife Science United States). Each sample studied was repeated twice and fluorescence signals from stained nuclei were acquired with $561 \mathrm{~nm}$ laser line and 610/20 nm emission filter using CytExpert 2.3 software. Analyses were performed using Kaluza Analysis 2.1 software (Beckman Coulter).To calculate the 2C DNA value, we used the formula below that study the linear relationship between fluorescence signals from stained nuclei of the IS and juniper samples.

2C DNA content $(\mathrm{pg})=$

$$
\left(\frac{\text { Sample } 2 \text { C peak mean }}{\text { Standard 2C peak mean }}\right) \times \text { Standard 2C DNA }(\mathrm{pg})
$$

\section{Supplementary information}

Supplementary information accompanies this paper at https://doi.org/10. 1186/s12862-020-01688-3.

Additional file 1. Genome size measurements of Juniperus samples.

Additional file 2. Collection information and field notes.

\section{Abbreviations}

balk, bal.: Juniperus sabina var. balkanensis; cpDNA: Chloroplast DNA; CV.: Cultivar; E Iberian Range: Eastern Iberian range; Freq: Frequency; g: Gram; GS: Genome size; IS: Internal standard; mg: Milligram; mM: Millimolar; na: Not applicable; ng: Nanogram; nrDNA: Nuclear DNA; PCOR: Principle coordinates ordination; pg: Picogram; PI: Propidium iodide; sab: Juniperus sabina var. sabina; SNP: Single Nucleotide Polymorphism; thu: Juniperus thurifera; T1: Type 1; T2: Type 2; ul: Microliter; var.: Variety

\section{Acknowledgements}

We thank Dr. Leonardo Gutiérrez (Andalusian Network of Botanical and Mycological Gardens in Natural Areas), the PhD student Juan Ortega-Vidal and the forestry agents of Natural Park Sierra de Baza for their assistance at field work. We also thank the General Directorate of Environment (Junta de Andalucía) for allowing us access to FAME database. Authors want to thank the National Council for Scientific Research in France (CNRS).

\section{Authors' contributions}

RPA, CF, SLU, CSM, and JA designed the study. CF, SLU, CSM, JA, and RPA collected plants and arranged logistics for collection permits and transport to RPA and SSY labs. PF performed DNA sequencing and analyses. SSY and NV conducted the ploidy analyses by flow cytometry. All authors contributed to the writing of the manuscript and have read and approved the final version of the manuscript.

\section{Funding}

This research supported by funds from Baylor University (project 032-4512 to RPA).

\section{Availability of data and materials}

DNA sequences are available from GenBank repository accessions: GenBank MT136620-MT136701 for the region: trnS-trnG intergenic spacer, complete sequence; TrnG, partial sequence; chloroplast.

GenBank MT137794-MT137875 for the region: 18S ribosomal RNA gene, partial sequence; internal transcribed spacer 1,5.8S ribosomal RNA gene, and internal transcribed spacer 2, complete sequence; and 265 ribosomal RNA gene, partial sequence.

Ethics approval and consent to participate

not applicable.

\section{Consent for publication}

not applicable.

\section{Competing interests}

The authors declare that they have no competing interests.

\section{Author details}

${ }^{1}$ Biology Department, Baylor University, Waco, TX 76798, USA. ${ }^{2}$ Present address: Key Laboratory of Bio-resources and Eco-environment, College of Life Sciences, Sichuan University, Chengdu, Sichuan 610064, China.

${ }^{3}$ Université Paris-Saclay, CNRS, AgroParisTech, Ecologie Systématique Evolution, 91405 Orsay, France. ${ }^{4}$ Institute of Integrative Biology of the Cell

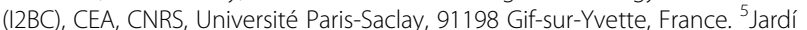
Botànic de la Universitat de València, 46008 València, Spain. ${ }^{6}$ Departamento de Biología Animal, Biología Vegetal y Ecología. Universidad de Jaén, 23071 Jaén, Spain. ${ }^{7}$ Departamento de Química Inorgánica y Orgánica, Universidad de Jaén, 23071 Jaén, Spain.

Received: 5 March 2020 Accepted: 9 September 2020

Published online: 09 November 2020

References

1. Otto SP, Whitton J. Polyploid incidence and evolution. Annu Rev Genet. 2000;34:401-37

2. Goulet BE, Roda F, Hopkins R. Hybridization in plants: old ideas, new techniques. Plant Physiol. 2017;173:65-78.

3. Husband BC, Baldwin SJ, Suda J. The incidence of polyploidy in natural plant populations: major patterns and evolutionary processes. In: Plant genome diversity volume 2: physical structure, behaviour and evolution of plant genomes. Vienna: Springer; 2013. p. 255-76.

4. Ahuja MR. Polyploidy in gymnosperms: revisited. Silvae Genet. 2005;54:59-69.

5. Adams RP, Schwarzbach AE. Phylogeny of Juniperus using nrDNA and four cpDNA regions. Phytologia. 2013;95:179-87.

6. Adams RP. Junipers of the world: the genus Juniperus. 4th ed. Bloomington, Indiana: Trafford Publishing; 2014

7. Farhat P, Hidalgo O, Robert T, Siljak-Yakovlev S, Leitch I, Adams RP, Bou Dagher Kharrat M. Polyploidy in the conifer genus Juniperus: an unexpectedly high rate. Front Plant Sci. 2019;10:676. https://doi.org/10.3389/pls.2019.00676.

8. Adams RP. Multiple evidences of past evolution are hidden in nrDNA of Juniperus arizonica and J. coahuilensis populations in the trans-Pecos, Texas region. Phytologia. 2017;99:38-47.

9. Adams RP. Allopatric hybridization and introgression between Juniperus maritima RP Adams and J. scopulorum Sarg.: evidence from nuclear and cpDNA and leaf terpenoids. Phytologia. 2015;97:55-66.

10. Adams RP. Allopatric hybridization and introgression between Juniperus maritima RP Adams and J. scopulorum Sarg. II. Additional evidence from 
nuclear and cpDNA genes in Montana, Wyoming, Idaho and Utah. Physiologia. 2015;97:187-99.

11. Adams RP, Wingate D. Hybridization between Juniperus bermudiana and $J$. virginiana in Bermuda. Phytologia. 2008:90:123-213.

12. Palma-Otal M, Moore W, Adams RP, Joswiak G. Morphological, chemical, and biogeographical analyses of a hybrid zone involving Juniperus virginiana and J. horizontalis in Wisconsin. Can J Bot. 1983;61:2733-46.

13. Terry RG, Nowak RS, Tausch RJ. Genetic variation in chloroplast and nuclear ribosomal DNA in Utah juniper (Juniperus osteosperma, Cupressaceae): evidence for interspecific gene flow. Am J Bot. 2000;87:250-8.

14. Vasek FC. The distribution and taxonomy of three western junipers. Brittonia. 1966;18:350-72.

15. Adams RP, Schwarzbach A, Tashev A. Chloroplast capture by a new variety, Juniperus sabina var. balkanensis RP Adams and AN Tashev, from the Balkan peninsula: A putative stabilized relictual hybrid between J. sabina and ancestral J. thurifera. Phytologia. 2016;98:100-11.

16. Farhat P, Siljak-Yakovlev S, Adams RP, Bou Dagher Kharrat M, Robert T. genome size variation and polyploidy in the geographical range of Juniperus sabina L. (Cupressaceae). Bot Lett. 2019;166:125-33. https://doi. org/10.1080/23818107.2019.1613262.

17. Adams RP, Boratynski A, Marcysiak K, Roma-Marzio F, Peruzzi L, Bartolucci F, Conti F, Mataraci T, Schwarzbach A. Discovery of Juniperus sabina var. balkanensis RP Adams and AN Tashev in Macedonia, Bosnia-Herzegovina, Croatia and central and southern Italy and relictual polymorphisms found in nrDNA. Phytologia. 2018;100:117-27.

18. Farhat P, Takvorian N, Avramidou M, Garraud L, Adams RP, Siljak-Yakovlev S, Bou Dagher Kharrat M, Robert T. First evidence for allo-triploid hybrids between Juniperus thurifera and J. sabina in a sympatric area in the French Alps. Accepted in Ann. For. Sci. Manuscript number is AFSC-D-19-00296R3; 2020. DOl : https://doi.org/10.1007/s13595-020-00969-7.

19. Aparicio JM, Uribe-Echebarria PM. Juniperus $x$ cerropastorensis, nuevo híbrido entre Juniperus sabina L. y Juniperus thurifera L. Toll Negre. 2009;11:6-13.

20. Veldman DJ. Fortran programming for the behavioral sciences. New York: Holt, Rinehart and Winston Publisher; 1967.

21. Adams RP. A comparison of multivariate methods for the detection of hybridization. Taxon. 1982;31:646-61.

22. Adams RP, Stoehr M. Multivariate detection of hybridization using conifer terpenes II: analyses of terpene inheritance patterns in Pseudotsuga menziesii F1 hybrids. Phytologia. 2013;95:42-57.

23. Siljak-Yakovlev S, Pustahija F, Šolić E, Bogunić F, Muratović E, Bašić N, Catrice $\mathrm{O}$, Brown S. Towards a genome size and chromosome number database of Balkan flora: C-values in 343 taxa with novel values for 242. Adv Sci Lett. 2010;3:190-213.

24. Vallès J, Garnatje T, Robin O, Siljak-Yakovlev S. Molecular cytogenetic studies in western Mediterranean Juniperus (Cupressaceae): a constant model of GC-rich chromosomal regions and rDNA loci with evidences for paleopolyploidy. Tree Genet Genom. 2015;11:1-8.

25. Nagano K, Matoba H, Yonemura K, Matsuda Y, Murata T, Hoshi Y. Karyotype analysis of three Juniperus species using fluorescence in situ hybridization (FISH) with two ribosomal RNA genes. Cytologia. 2007;72:37-42.

26. Ramsey J, Schemske DW. Pathways, mechanisms, and rates of polyploid formation in flowering plants. Annu Rev Ecol Evol Syst. 1998:29:467-501.

27. Tayalé A, Parisod C. Natural pathways to polyploidy in plants and consequences for genome reorganization. Cytogenet Genome Res. 2013; 140:79-96.

28. Husband $B C$. The role of triploid hybrids in the evolutionary dynamics of mixed-ploidy populations. Biol J Linn Soc. 2004:82:537-46.

29. Adams RP, Farhat P, Shuka L, Siljak-Yakovlev S. Discovery of Juniperus sabina var. balkanensis RP Adams and AN Tashev in Albania and relictual polymorphisms found in nrDNA. Phytologia. 2018;100:187-94

30. Stebbins GL. The role of hybridization in evolution. Proc Am Phil Soc. 1959; 103:231-51.

31. Arnold ML. Anderson's and Stebbins' prophecy comes true: genetic exchange in fluctuating environments. Syst Bot. 2016;41:4-16.

32. Mallet J, Besansky N, Hahn MW. How reticulated are species? BioEssays. 2016;38:140-9

33. Wagner W Jr. Biosystematics and evolutionary noise. Taxon. 1970;19:146-51.

34. Rieseberg LH. Hybrid origins of plant species. Annu Rev Ecol Evol Syst. 1997; 28:359-89

35. Mallet J. Hybrid speciation. Nature. 2007;446:279-83.
36. Baldwin BG, Sanderson MJ, Porter JM, Wojciechowski MF, Campbell CS, Donoghue MJ. The ITS region of nuclear ribosomal DNA: a valuable source of evidence on angiosperm phylogeny. Ann Mo Bot Gard. 1995;82:247-77.

37. Giudicelli GC, Mäder G, Silva-Arias GA, Zamberlan PM, Bonatto SL, Freitas LB Secondary structure of nrDNA internal transcribed spacers as a useful tool to align highly divergent species in phylogenetic studies. Genet Mol Biol. 2017;40:191-9.

38. Adams RP, Boratynski A, Mataraci T. Discovery of Juniperus sabina var. balkanensis RP Adams and AN Tashev in western Turkey (Anatolia). Phytologia. 2017;99:22-31.

39. Adams RP, Mataraci T, Tashev AN. The composition of the leaf essential oils of I sabina var balkanensis: chemotypes high in trans-sabinyl acetate and methyl eugenol discovered in three natural populations. Phytologia. 2018; 100:45-50.

40. Grant V. Plant speciation. New York: Columbia University Press; 1981.

41. Ramsey J, Schemske DW. Neopolyploidy in flowering plants. Annu Rev Ecol Evol Syst. 2002;33:589-639.

42. Schinkel CC, Kirchheimer B, Dullinger S, Geelen D, De Storme N, Hörandl E. Pathways to polyploidy: indications of a female triploid bridge in the alpine species Ranunculus kuepferi (Ranunculaceae). Plant Syst Evol. 2017;303:1093108.

43. Wang J, Huo B, Liu W, Li D, Liao L. Abnormal meiosis in an intersectional allotriploid of Populus $L$. and segregation of ploidy levels in $2 \times \times 3 \times$ progeny. PLoS One 2017;12:e0181767. https://doi.org/https://doi.org/10.1371/journal. pone.0181767.

44. Adams RP. Inheritance of chloroplasts and mitochondria in conifers: a review of paternal, maternal, leakage and facultative inheritance. Phytologia. 2019;101:134-8.

45. Zhou R, Gong X, Boufford D, Wu C-I, Shi S. Testing a hypothesis of unidirectional hybridization in plants: observations on Sonneratia, Bruguiera and Ligularia. BMC Evol Biol. 2008:8:1-9.

46. Field D, Ayre D, Whelan $R$, Young A. Patterns of hybridization and asymmetrical gene flow in hybrid zones of the rare Eucalyptus aggregata and common E. rubida. Heredity. 2011;106:841-53.

47. Wallace LE, Culley TM, Weller SG, Sakai AK, Kuenzi A, Roy T, Wagner WL, Nepokroeff M. Asymmetrical gene flow in a hybrid zone of Hawaiian Schiedea (Caryophyllaceae) species with contrasting mating systems. PLoS One. 2011;6:e24845.

48. Godbout J, Yeh FC, Bousquet J. Large-scale asymmetric introgression of cytoplasmic DNA reveals Holocene range displacement in a north American boreal pine complex. Ecol Evol. 2012;2:1853-66.

49. Li Z, Zou J, Mao K, Lin K, Li H, Liu J, Källman T, Lascoux M. Population genetic evidence for complex evolutionary histories of four high altitude juniper species in the Qinghai-Tibetan plateau. Evolution. 2011; 66:831-45.

50. Lepais O, Petit R, Guichoux E, Lavabre J, Alberto F, Kremer A, Gerber S. Species relative abundance and direction of introgression in oaks. Mol Ecol. 2009;18:2228-42.

51. Adams RP. Hybridization between Juniperus grandis, J. occidentalis and J. osteosperma in Northwest Nevada I: Terpenes, leviathan mine, Nevada. Phytologia. 2013;95:58-69.

52. Adams RP. Hybridization between Juniperus grandis, J. occidentalis and J. osteosperma in Northwest Nevada II: Terpenes, Buffalo Hills, northwestern Nevada. Phytologia. 2013;95:107-14.

53. Adams RP, Kistler J. Hybridization between Juniperus erythrocarpa Cory and Juniperus pinchotii Sudworth in the Chisos mountains, Texas. Southwest Natl. 1991;36:295-301.

54. Adams RP, Johnson S, Coombes AJ, Caamaño L, González-Elizondo MS. Preliminary examination of hybridization and introgression between Juniperus flaccida and J. poblana: nrDNA and cpDNA sequence data. Phytologia. 2018;100:145-52.

55. Levin DA. The role of chromosomal change in plant evolution. New York: Oxford University Press; 2002.

56. Petit C, Bretagnolle F, Felber F. Evolutionary consequences of diploidpolyploid hybrid zones in wild species. Trends Ecol Evol. 1999;14:306-11.

57. Husband BC, Sabara HA. Reproductive isolation between autotetraploids and their diploid progenitors in fireweed, Chamerion angustifolium (Onagraceae). New Phytol. 2004;161:703-13.

58. Montesinos D, García-Fayos P, Verdú M. Masting uncoupling: mast seeding does not follow all mast flowering episodes in a dioecious juniper tree. Oikos. 2012;121:1725-36. 
59. Montesinos D, De Luís M, Verdu M, Raventós J, García-Fayos P. When, how and how much: gender-specific resource-use strategies in the dioecious tree Juniperus thurifera. Ann Bot. 2006;98:885-9.

60. Rodriquez-García E, Olano JM, Leroux O, Mezquida ET. Deciphering the role of reproductive investment, pollination success and predispersal seed predation on reproductive output in Juniperus thurifera. Plant Ecol Divers. 2019;12:37-49

61. Amaral-Franco J, Juniperus L. In: Castroviejo S, Laínz M, López González G, Monserrat P, Muñoz Garmendia F, Paiva J, Villar L, editors. In Flora Ibérica. Plantas Vasculares de la Península Ibérica e Islas Baleares. Madrid: Real Jardín Botánico; 1986. p. 181-8.

62. Pérez-Latorre AV, Cabezudo B, Juniperus L. In: Blanca G, Cabezudo B, Cueto M, Morales CT, Salazar C, editors. Flora Vascular de Andalucía Oriental. Granada: Publishing Services of Almeria, Granada, Jaen \& Malaga Universities; 2011. p. 87-90.

63. Junta de Andalucía. 2019. Agroclimatic stations data. Agricultural and fisheries research and training institute. Counseling of agriculture, livestock, fisheries and sustainable development. (https://www.juntadeandalucia.es/ agriculturaypesca/ifapa/ria/servlet/FrontController), accessed 2019.

64. Levetin E. A long-term study of winter and early spring tree pollen in the Tulsa, Oklahoma atmosphere. Aerobiologia. 1998;14:21-8.

65. Frenguelli G, Spieksma FTM, Bricchi E, Romano B, Mincigrucci G, Nikkels A, Dankaart W, Ferranti F. The influence of air temperature on the starting dates of the pollen season of Alnus and Populus. Grana. 1991; 30:196-200

66. Boyer WD. Air temperature, heat sums, and pollen shedding phenology of longleaf pine. Ecology. 1973;54:420-6.

67. Mohanty RP, Buchheim MA, Anderson J, Levetin E. Molecular analysis confirms the long-distance transport of Juniperus ashei pollen. PLoS One. 2017;12:e0173465.

68. Szczepanek K, Myszkowska D, Worobiec E, Piotrowicz K, Ziemianin M, BielecBąkowska Z. The long-range transport of Pinaceae pollen: an example in Kraków (southern Poland). Aerobiologia. 2017;33:109-25.

69. Neale DB, Wheeler NC. The conifers. In: The conifers: genomes, variation and evolution. Cham: Springer International Publishing; 2019. p. 1-21.

70. Stewart JF, Tauer CG, Nelson C. Bidirectional introgression between loblolly pine (Pinus taeda L.) and shortleaf pine (P. echinata Mill.) has increased since the 1950s. Tree Genet Genom. 2012:8:725-35.

71. Sarvas R. Investigations on the flowering and seed crop of Pinus silvestris. Comm Instituti Forestalis Fenniae. 1962:53:1-198.

72. Koski V. A study of pollen dispersal as a mechanism of gene flow in conifers. Comm Instituti Forestalis Fenniae. 1970;70:1-78.

73. Nichols H, Kelly P, Andrews J. Holocene palaeo-wind evidence from palynology in Baffin Island. Nature. 1978;273:140-2.

74. Campbell ID, McDonald K, Flannigan MD, Kringayark J. Long-distance transport of pollen into the Arctic. Nature. 1999;399:29-30.

75. Lindgren D, Paule L, Xihuan S, Yazdani R, Segerström U, Wallin J-E, Lejdebro ML. Can viable pollen carry scots pine genes over long distances? Grana. 1995;34:64-9.

76. Varis S, Pakkanen A, Galofré A, Pulkkinen P. The extent of south-north pollen transfer in Finnish scots pine. Silva Fenn. 2009:43:717-26.

77. Williams CG. Long-distance pine pollen still germinates after meso-scale dispersal. Am J Bot. 2010;97:846-55.

78. Caramiello R, Potenza A, Siniscalco C. Relationship between distribution of Juniperus communis L. ssp. communis in western Alps, its pollen morphology and viability. Allionia. 1990;30:65-74.

79. Robledo-Arnuncio JJ. Wind pollination over mesoscale distances: an investigation with scots pine. New Phytol. 2011;190:222-33.

80. Robledo-Arnuncio J, Gil L. Patterns of pollen dispersal in a small population of Pinus sylvestris L. revealed by total-exclusion paternity analysis. Heredity. 2005:94:13-22

81. Junta de Andalucía. 2019. Threatened Flora system of Andalusia (FAME). Accessed 2019.

82. Taylor SA, Larson EL, Harrison RG. Hybrid zones: windows on climate change. Trends Ecol Evol. 2015;30:398-406.

83. Hamilton JA, Amanda R, Aitken SN. Fine-scale environmental variation contributes to introgression in a three-species spruce hybrid complex. Tree Genet Genomes. 2015;11:1-14.

84. Sora D, Kron P, Husband B. Genetic and environmental determinants of unreduced gamete production in Brassica napus, Sinapis arvensis and their hybrids. Heredity. 2016;117:440-8.
85. Wang J, Li D, Shang F, Kang X. High temperature-induced production of unreduced pollen and its cytological effects in Populus. Sci Rep. 2017;7:5281.

86. Romo A, Hidalgo O, Boratyński A, Sobierajska K, Jasińska AK, Vallès J, Garnatje T. Genome size and ploidy levels in highly fragmented habitats: the case of western Mediterranean Juniperus (Cupressaceae) with special emphasis on J. thurifera L. Tree Genet Genomes. 2013;9:587-99.

87. Peña J, Cuadrat J, Sánchez M. El Clima de la Provincia de Teruel. Cartillas Turolenses, no 20. Teruel: Instituto de Estudios Turolenses; 2002.

88. Aupí V. El triángulo de hielo (Teruel - Calamocha - Molina de Aragón). Estudio climático del Polo del Frío español. Teruel: Dobleuve Comunicación; 2014.

89. Fitchett JM, Grab SW, Thompson DI. Plant phenology and climate change: Progress in methodological approaches and application. Prog Phys Geogr. 2015;39:460-82.

90. Wadgymar SM, Ogilvie JE, Inouye DW, Weis AE, Anderson JT. Phenological responses to multiple environmental drivers under climate change: insights from a long-term observational study and a manipulative field experiment. New Phytol. 2018;218:517-29

91. Adams RP, Bartel J, Price R. A new genus, Hesperocyparis, for the cypresses of the Western hemisphere (Cupressaceae). Phytologia. 2009;91:160-85.

92. Adams RP, Kauffmann ME. Variation in nrDNA, and cpDNA of Juniperus californica, J. grandis, J. occidentalis and J. osteosperma (Cupressaceae). Phytologia. 2010;92:266-76.

93. Adams RP. Statistical character weighting and similarity stability. Brittonia. 1975;27:305-16.

94. Garnatje T, Vallès J, Garcia S, Hidalgo O, Sanz M, Canela MÁ, Siljak-Yakovlev S. Genome size in Echinops L. and related genera (Asteraceae, Cardueae): karyological, ecological and phylogenetic implications. Biol Cell. 2004;96: 117-24.

95. Bourge M, Brown SC, Siljak-Yakovlev S. Flow cytometry as tool in plant sciences, with emphasis on genome size and ploidy level assessment. Genet Appl. 2018;2:1-12.

\section{Publisher's Note}

Springer Nature remains neutral with regard to jurisdictional claims in published maps and institutional affiliations.

Ready to submit your research? Choose BMC and benefit from:

- fast, convenient online submission

- thorough peer review by experienced researchers in your field

- rapid publication on acceptance

- support for research data, including large and complex data types

- gold Open Access which fosters wider collaboration and increased citations

- maximum visibility for your research: over $100 \mathrm{M}$ website views per year

At $\mathrm{BMC}$, research is always in progress.

Learn more biomedcentral.com/submissions 